Article

\title{
Exploring the Iron Oxide Functionalized Biobased Carbon-silica-polyethyleneimine Composites for Hexavalent Chromium Removal from Dilute Aqueous Solutions
}

\author{
Mpho Cynthia Qhubu ${ }^{1}$, Philiswa Nosizo Nomngongo ${ }^{2}\left(\mathbb{D}\right.$ and Vusumzi Emmanuel Pakade ${ }^{1, *(1)}$ \\ 1 Department of Chemistry, Faculty of Applied and Computer Sciences, Vaal University of Technology, \\ Private Bag x 021, Vanderbijlpark 1900, South Africa; 213102382@edu.vut.ac.za \\ 2 Department of Science and Innovation (DSI)/National Research Foundation (NRF) South African Research \\ Chair Initiative (SARChI), Nanotechnology for Water, University of Johannesburg, \\ Johannesburg 2711, South Africa; pnnomngongo@uj.ac.za \\ * Correspondence: vusumzip@vut.ac.za; Tel.: +27-16-950-6629
}

check for updates

Citation: Qhubu, M.C.; Nomngongo, P.N.; Pakade, V.E. Exploring the Iron Oxide Functionalized Biobased Carbon-silica-polyethyleneimine Composites for Hexavalent Chromium Removal from Dilute Aqueous Solutions. Water 2021, 13, 3081. https://doi.org/10.3390/ w13213081

Academic Editor: Laura Bulgariu

Received: 26 August 2021

Accepted: 21 October 2021

Published: 2 November 2021

Publisher's Note: MDPI stays neutral with regard to jurisdictional claims in published maps and institutional affiliations.

Copyright: (c) 2021 by the authors. Licensee MDPI, Basel, Switzerland. This article is an open access article distributed under the terms and conditions of the Creative Commons Attribution (CC BY) license (https:/ / creativecommons.org/licenses/by/ $4.0 /)$.

\begin{abstract}
The contamination of water resources by toxic hexavalent chromium remains a challenge. In this study, amino-functionalized iron oxide biobased carbon-silica composites were prepared through co-precipitation of Fe(II) and Fe(III) over Macadamia activated carbon and explored as feasible adsorbents for the removal of $\mathrm{Cr}(\mathrm{VI})$ from dilute aqueous solutions. The energy dispersive spectroscopy (EDS) elemental analysis confirmed the existence of $\mathrm{Fe}, \mathrm{Si}, \mathrm{O}$, and $\mathrm{C}$ atoms, which form the backbone of the composite. The FTIR also showed the presence of Fe-O and Si-O-Si and Si-OH spectral bands, affirming the backbone of the adsorbents. $\mathrm{Cr}(\mathrm{VI})$ adsorption efficiency $(5.76 \mathrm{mg} / \mathrm{g})$ was achieved at $\mathrm{pH} 1$ when an initial concentration of $2.5 \mathrm{mg} / \mathrm{L}$, contact time of $90 \mathrm{~min}$, and dosage concentration of $1.7 \mathrm{~g} / \mathrm{L}$ were used. The data were best described by the Langmuir adsorption model and pseudo-second-order rate model. $\Delta G^{\circ}(-3$ to $-12 \mathrm{~kJ} / \mathrm{mol})$ and $\Delta H^{\circ}(46,12$ and $5 \mathrm{~kJ} / \mathrm{mol})$ values affirmed that the adsorption of $\mathrm{Cr}(\mathrm{VI})$ was spontaneous and endothermic and dominated by chemical interactions.
\end{abstract}

Keywords: adsorption; activated carbon; co-precipitation; functionalization; iron oxide; chromium(VI)

\section{Introduction}

Chromium, similar to other heavy metals, is a menace to the environment as it persists and is non-biodegradable [1]. Chromium can be present in both anionic and cationic forms in aqueous media depending on the $\mathrm{pH} /$ Eh conditions. In cationic form, $\mathrm{Cr}(\mathrm{III})$ is the most stable oxidation state. At trace concentrations, $\mathrm{Cr}$ (III) is a micronutrient required by animals and humans [2]. The anionic chromium, $\mathrm{Cr}(\mathrm{VI})$, because of its carcinogenic and genotoxic properties, is classified as the 17th most toxic hazardous substance in the environment by the Agency for Toxic Substances and Disease Registry. The major sources of $\mathrm{Cr}(\mathrm{VI})$ in the environment are through anthropogenic activities because the kinetic reactions governing the conversion of natural $\mathrm{Cr}(\mathrm{III})$ to $\mathrm{Cr}(\mathrm{VI})$ are very slow [3,4]. In particular, $\mathrm{Cr}(\mathrm{VI})$ is a major element for the electroplating and stainless-steel production industries [5]. These industries use lots of water during their production, hence, the probability of $\mathrm{Cr}(\mathrm{VI})$ compounds leaching to the environment is too high [6]. Industrial wastewater containing chromium concentrations in the range of 0.5 to $270 \mathrm{mg} / \mathrm{L}$ have been reported [7]. The World Health Organization put stringent regulations to limit the amount of $\mathrm{Cr}(\mathrm{VI})$ in drinking water and surface water to $0.05 \mathrm{mg} / \mathrm{L}$ and $0.1 \mathrm{mg} / \mathrm{L}$, respectively [6].

On one hand, current treatment techniques for the elimination of toxic $\mathrm{Cr}(\mathrm{VI})$ from water, which include ion exchange, membrane separation, and chemical precipitation, have limitations [8-10]. Membrane technology suffers from clogging and fouling [11], ion exchange is limited by high costs and fouling of resins [10], and chemical precipitation is 
made difficult by the generation of toxic sludge which is costly to dispose of [12]. Adsorption on the other hand is highly favored due to simplicity in its design, ease of operation, low cost, low energy inputs, and use of cost-effective adsorbents $[5,13]$. However, its costeffectiveness is dependent on the adsorbent being used, and its regeneration capabilities.

Biobased carbons, such as activated carbons (ACs), are widely used in the industry on a large scale as adsorbents for water purification, catalytic processes, and separation processes [14]. Activated carbons are applied in adsorption processes because of their large surface area, porous structure, and low cost of preparation [14-16]. Although efficient adsorption capacities have been reported for the removal of $\mathrm{Cr}(\mathrm{VI})$ using powdered ACs [17], challenges of separating the adsorbent from the solution have risen concerns of spent carbons being potential secondary pollutants.

The use of iron-based adsorbents in the removal of hexavalent chromium from aqueous solutions has attracted considerable research interest because of their power to transform $\mathrm{Cr}(\mathrm{VI})$ into $\mathrm{Cr}(\mathrm{III})$ during removal $[18,19]$. However, the iron-based materials have a shortfall of being applicable in a limited $\mathrm{pH}$ range due to precipitation of iron, and to address that, $\mathrm{SiO}_{2}$ is often coated on the materials for applicability in a wider $\mathrm{pH}$ range [18]. Inorganic silica $\left(\mathrm{SiO}_{2}\right)$ is widely employed as a supporting material due to its favorable characteristics of being stable under acidic conditions, its inertness to redox reaction, and its high content of hydroxyl groups on its surface which allows further functionalization, ease of binding, and attachment of ligands [20].

Amino functionalized materials such as m-phenylenediamine, polyethyleneimine (PEI), polypyrrole (PPy), CM-dextran, and chitosan have also been explored as supporting materials for nanoparticles owing to their low cost of preparations and operations, porous structures, environmental stability, and regeneration properties [21]. The high content of deprotonated amine groups is critical for the adsorption of trace metal ions through electrostatic interactions and hydrogen bonding [22]. However, metal ions such as $\mathrm{Cr}(\mathrm{VI})$ undergo reductive transformation upon contact with electron donors to yield less toxic $\mathrm{Cr}$ (III) ions [23]. Immobilization of the formed-Cr(III) is also possible because the amino groups act as Lewis bases and form complexes with the $\mathrm{Cr}$ (III) [21]. The latter prepares the adsorbents via the functionalization of PEI to be of particular interest to researchers because both the adsorption and reduction mechanisms can be explored for the removal of $\mathrm{Cr}(\mathrm{VI})$. As such, adsorbents prepared by functionalization of PEI on a substrate have been widely used in the literature for the removal of $\mathrm{Cr}(\mathrm{VI})$ [24-29]. However, none of these were prepared from silica supported on biobased carbons originating from Macadamia nutshells. This study aimed to synthesize the iron oxide functionalized biobased carbon-silica-polyethyleneimine composites for the abatement of $\mathrm{Cr}(\mathrm{VI})$ in dilute aqueous solutions. The one-variable-at-a-time approach was used to study the effect of time, temperature, mass, concentration, and $\mathrm{pH}$ in batch mode.

\section{Experimental Methods}

\subsection{Chemical Reagents}

Potassium hydroxide $(\mathrm{KOH})$, sodium hydroxide $(\mathrm{NaOH})$, hydrochloric acid $(32 \% \mathrm{HCl})$, sulfuric acid $\left(98 \% \mathrm{H}_{2} \mathrm{SO}_{4}\right)$, iron (III) chloride $\left(\mathrm{FeCl}_{3} \cdot 6 \mathrm{H}_{2} \mathrm{O}\right)$, iron (II) chloride $\left(\mathrm{FeCl}_{2} \cdot 4 \mathrm{H}_{2} \mathrm{O}\right)$, potassium dichromate $\left(\mathrm{K}_{2} \mathrm{Cr}_{2} \mathrm{O}_{7}\right), 1,5^{\prime}$-diphenylcarbazide (DPC), ethanol, tetraethyl orthosilicate (TEOS), $N, N^{\prime}$-dimethylformamide (DMF), acetic acid, 3-glycidyloxypropyltrimet hoxysilane (GPS), and branched polyethyleneimine $\mathrm{Mw}=2500$ (PEI) were purchased from LabChem and Merck Chemical Co. (Johannesburg, South Africa) and were used without further purification. All chemicals were of reagent grade purity. Commercial Macadamia activated carbon was supplied by Innovation Carbon Pty LTD (Johannesburg, South Africa). The water used in this study for the preparation of stock, calibration standard, and working solutions was purified using Siemens LaboStar equipment (Warrendale, PA, USA). Duplicate batch adsorption experiments were conducted on a Scientech Ultrasonic Bath 703 supplied by Labotec (Johannesburg, South Africa). HI 2210 from Hanna Instruments (Johan- 
nesburg, South Africa) was used to adjust the $\mathrm{pH}$ of solutions using diluted hydrochloric acid and sodium hydroxide solutions.

\subsection{Preparation of Adsorbents}

(i) Hydroxylation of $A C$

Macadamia activated carbon (AC) $(150-300 \mu \mathrm{m})$ was firstly pre-treated in $5 \mathrm{~mol} / \mathrm{L}$ $\mathrm{KOH}$ to achieve more porosity and possibly introduce $\mathrm{OH}^{-}$groups on its surface for ease of binding and functionalization. The resultant product was then filtered and washed several times with ultrapure water. The product was further neutralized by washing with $1 \%$ acetic acid, then dried in an oven at $60^{\circ} \mathrm{C}$ for $24 \mathrm{~h}$ and finally labeled $\mathrm{AC}-\mathrm{KOH}$.

(ii) Preparation of iron oxide modified $\mathrm{AC}\left(\mathrm{AC}-\mathrm{Fe}_{3} \mathrm{O}_{4}\right)$

Iron oxide was immobilized on the carbon surface through a co-precipitation method by dissolving a known amount of $\mathrm{FeCl}_{3} \cdot 6 \mathrm{H}_{2} \mathrm{O}$ and $\mathrm{FeCl}_{2} \cdot 4 \mathrm{H}_{2} \mathrm{O}$ salts in $300 \mathrm{~mL}$ ultrapure water and refluxed at $70{ }^{\circ} \mathrm{C}$ under a nitrogen flow for $2 \mathrm{~h}$. About $5 \mathrm{~g}$ of $\mathrm{AC}-\mathrm{KOH}$ was added to the $\mathrm{Fe}^{2+} / \mathrm{Fe}^{3+}$ solution to obtain a 1:1 ratio and stirred for half an hour while maintaining the $\mathrm{pH}$ between 10 and 11 using $5 \mathrm{~mol} / \mathrm{L} \mathrm{NaOH}$ solution. The solid material was separated by filtration, then washed several times with ultrapure water and ethanol and dried at $60^{\circ} \mathrm{C}$ overnight.

(iii) Preparation of $\mathrm{AC}-\mathrm{Fe}_{3} \mathrm{O}_{4}-\mathrm{SiO}_{2}$

The method reported by [30] was used to prepare the silica-coated biobased carbon. About $5 \mathrm{~g}$ of the recovered $\mathrm{AC}-\mathrm{Fe}_{3} \mathrm{O}_{4}$ was refluxed in a $500 \mathrm{~mL}$ water and ethanol solution of $4: 1$ ratio at $60^{\circ} \mathrm{C}$ under nitrogen flow. Tetraethyl orthosilicate (TEOS) was added dropwise to the solution to form $\mathrm{AC}-\mathrm{Fe}_{3} \mathrm{O}_{4}-\mathrm{SiO}_{2}$ maintaining the $\mathrm{pH}$ in basic conditions ( $\mathrm{pH} 9$ to 11). The formed product $\mathrm{AC}-\mathrm{Fe}_{3} \mathrm{O}_{4}-\mathrm{SiO}_{2}$ was separated by filtration, washed several times with ultrapure water and ethanol, and dried at $60^{\circ} \mathrm{C}$ overnight.

\section{(iv) Preparation of amino-modified adsorbent $\left(\mathrm{AC}-\mathrm{Fe}_{3} \mathrm{O}_{4}-\mathrm{SiO}_{2}-\mathrm{PEI}\right)$}

To bind the PEI ligand on $\mathrm{AC}-\mathrm{Fe}_{3} \mathrm{O}_{4}-\mathrm{SiO}_{2}$, the material was first hydroxylated using a method reported by [20] to increase the density of hydroxyl groups on the adsorbent surface. A $500 \mathrm{~mL}$ piranha solution $\left(3: 1 v / v \mathrm{H}_{2} \mathrm{SO}_{4}: \mathrm{H}_{2} \mathrm{O}_{2}\right)$ was prepared and allowed to cool for $24 \mathrm{~h}$. About $5 \mathrm{~g}$ of $\mathrm{AC}-\mathrm{Fe}_{3} \mathrm{O}_{4}-\mathrm{SiO}_{2}$ was then added to the cooled piranha solution and sonicated for 10 min under nitrogen flow. The solid sample was then separated by centrifuge and washed several times with ultrapure water and ethanol followed by drying at $60{ }^{\circ} \mathrm{C}$ for $12 \mathrm{~h}$. To the solid sample, $10 \mathrm{~mL}$ of 3-glycidyloxypropyltrimethoxysilane (GPS) and $20 \mathrm{~mL}$ toluene were added and stirred at $70^{\circ} \mathrm{C}$ for $8 \mathrm{~h}$ under nitrogen flow. The adsorbent was separated from the solution by a centrifuge, washed several times with ultrapure water and ethanol, and dried at $60^{\circ} \mathrm{C}$ overnight. About $5 \mathrm{~g}$ of GPS-treated AC- $-\mathrm{Fe}_{3} \mathrm{O}_{4}-\mathrm{SiO}_{2}$ was refluxed in a $5 \%$ solution of branched polyethyleneimine (PEI) $100 \mathrm{~mL}$ at $70{ }^{\circ} \mathrm{C}$ for $12 \mathrm{~h}$. The material was filtered and washed several times with ultrapure water and ethanol, then dried at $60^{\circ} \mathrm{C}$ in an oven overnight. The resultant product was designated $\mathrm{AC}-\mathrm{Fe}_{3} \mathrm{O}_{4}-\mathrm{SiO}_{2}$-PEI.

\subsection{Adsorption Experiments}

Batch adsorption experiments were performed using AC- $\mathrm{Fe}_{3} \mathrm{O}_{4}, \mathrm{AC}-\mathrm{Fe}_{3} \mathrm{O}_{4}-\mathrm{SiO}_{2}$, and $\mathrm{AC}-\mathrm{Fe}_{3} \mathrm{O}_{4}-\mathrm{SiO}_{2}-\mathrm{PEI}$ in duplicate for the adsorption of $\mathrm{Cr}(\mathrm{VI})$. Parameters such as solution $\mathrm{pH}(1-12)$, contact time (5-150 min), initial $\mathrm{Cr}(\mathrm{VI})$ concentration (1-12.5 mg/L), mass of adsorbent $(0.05-3.0 \mathrm{~g})$ and temperature $\left(25,35\right.$ and $\left.45^{\circ} \mathrm{C}\right)$ were investigated by varying one parameter at a time while keeping others constant. Diluted solutions $(0.1 \mathrm{~mol} / \mathrm{L})$ of $\mathrm{HCl}$ and $\mathrm{NaOH}$ were used to adjust the $\mathrm{pH}$ of the solution. An ultrasonicator (Scientech ultrasonic cleaner 703) set at low-frequency $\mathrm{H} 1$ was used for agitation and contact between the adsorbent and $\mathrm{Cr}(\mathrm{VI})$ solution. The total chromium and chromium (VI) remaining after adsorption were determined using a flame atomic absorption spectroscopy (AA-7000 Shimazu, Kyoto, Japan), and UV-Vis spectrophotometer (Evolution 220, ThermoScientific, 
Johannesburg, South Africa), respectively. The $\mathrm{Cr}(\mathrm{VI})$ complex was developed by reacting $0.1 \mathrm{~mol} / \mathrm{L}$ of 1,5'-diphenylcarbazide solution in 10\% sulfuric acid solution and the purplish solutions were analyzed with the UV-Vis at a wavelength of $540 \mathrm{~nm}$. The adsorption capacity $\left(q_{e}\right)$ and percent (\%R) removal and were calculated using Equations (1) and (2), respectively.

$$
\begin{gathered}
q_{e}=\frac{V\left(C_{o}-C_{e}\right)}{W} \\
\% \text { Removal }=\frac{\left(C_{o}-C_{e}\right)}{C_{o}} \cdot 100
\end{gathered}
$$

where $C_{o}$ is the analyte initial concentration $(\mathrm{mg} / \mathrm{L}), C_{e}$ is the final concentration $(\mathrm{mg} / \mathrm{L})$, $M$ is the mass of the adsorbent (g) and $V$ is the volume of the eluent (L).

\subsection{Adsorption Isotherms}

The Langmuir (Equation (3)), Freundlich (Equation (4)), and Dubinin-Radushrkevich (Equation (5)) adsorption isotherms were used to deduce the removal mechanisms, the adsorption affinity and intensity of adsorption for $\mathrm{Cr}(\mathrm{VI})$ onto $\mathrm{AC}-\mathrm{Fe}_{3} \mathrm{O}_{4}, \mathrm{AC}-\mathrm{Fe}_{3} \mathrm{O}_{4}-\mathrm{SiO}_{2}$, and $\mathrm{AC}-\mathrm{Fe}_{3} \mathrm{O}_{4}-\mathrm{SiO}_{2}-\mathrm{PEI}$ adsorbents. The equilibrium data were fitted into nonlinear models, as illustrated in Equations (3)-(5). The two well-known two-parameter models describe the adsorption of adsorbates onto adsorbents in two distinct phenomena. The Langmuir isotherm predicts the adsorption to proceed by a monolayer attachment of adsorbate on a single binding site that is on a homogeneous adsorbent surface. The Langmuir further assumes that no interactive bonding between adsorbates from adjacent sites occurs [31]. Conversely, the Freundlich isotherm allows for the interaction of adsorbates from adjacent active sites to take place, thus resulting in a heterogeneous surface with a multi-layered coverage. The Dubinin-Radushkevich isotherm can be used to confirm if the adsorption process is through physical or chemical interactions.

$$
\begin{gathered}
q_{e}=\frac{q_{m L} b C_{e}}{\left(1+b C_{e}\right)} \\
q_{e}=K_{F} C_{e}^{1 / n} \\
q_{e}=q_{m D R} \exp \left\{-K_{D R}\left[R T \ln \left(1+\frac{1}{C_{e}}\right)\right]^{2}\right\}
\end{gathered}
$$

where $b$ is the Langmuir isotherm constant $(\mathrm{L} / \mathrm{mg}), q_{m L}$ is the adsorption capacity at equilibrium $(\mathrm{mg} / \mathrm{g}), K_{F}$ is Freundlich constant $(\mathrm{mg} / \mathrm{g})(\mathrm{mg} / \mathrm{L})^{-1 / n}, n$ is the Freundlich adsorption intensity exponent (dimensionless), $q_{m D R}$ is the Dubinin-Radushkevich adsorption capacity $(\mathrm{mg} / \mathrm{g}), K_{D R}$ is the Dubinin-Radushkevich isotherm constant $\left(\mathrm{mol}^{2} / \mathrm{kJ}^{2}\right), R$ is the gas constant $(8.314 \mathrm{~J} /(\mathrm{mol} \mathrm{K}))$ and $T$ is temperature $(\mathrm{K})$.

\section{Results and Discussion}

\subsection{Adsorbent Characterization}

Figure 1 displays the FTIR spectra of $\mathrm{AC}-\mathrm{Fe}_{3} \mathrm{O}_{4}, \mathrm{AC}-\mathrm{Fe}_{3} \mathrm{O}_{4}-\mathrm{SiO}_{2}$, and $\mathrm{AC}-\mathrm{Fe}_{3} \mathrm{O}_{4}-\mathrm{SiO}_{2}-$ PEI. The vibration of Fe-O stretch in $\mathrm{Fe}_{3} \mathrm{O}_{4}$ was observed at $533.99 \mathrm{~cm}^{-1}$ together with the sp ${ }^{2} \mathrm{C}=\mathrm{C}$ bonds of the active carbon at 441 to $406 \mathrm{~cm}^{-1}$. Compared to $\mathrm{AC}-\mathrm{Fe}_{3} \mathrm{O}_{4}$, new bands appeared in $\mathrm{AC}-\mathrm{Fe}_{3} \mathrm{O}_{4}-\mathrm{SiO}_{2}$ at $1054.45 \mathrm{~cm}^{-1}$ assigned to the stretching vibrations of Si-O-Fe [21] and/or C-O-C [28], while those at 948.73 and $791.46 \mathrm{~cm}^{-1}$ were assigned to the asymmetric and symmetric stretches of $\mathrm{Si}-\mathrm{O}-\mathrm{Si}$ of the $\mathrm{SiO}_{2}$. The $\mathrm{AC}-\mathrm{Fe}_{3} \mathrm{O}_{4}-\mathrm{SiO}_{2}-$ PEI exhibited a peak at $3289 \mathrm{~cm}^{-1}$ assigned to the $-\mathrm{OH}$ stretch which overlaps with the $\mathrm{NH}$-stretch of the amine groups of PEI and the peaks at 2932.34 and $2816.03 \mathrm{~cm}^{-1}$ were assigned to the asymmetric and symmetric $-\mathrm{CH}_{2}$ - stretching vibrations of the ethyl groups on PEI branches [32]. The new peaks at 1658,1570 , and $1454 \mathrm{~cm}^{-1}$ in $\mathrm{AC}-\mathrm{Fe}_{3} \mathrm{O}_{4}-\mathrm{SiO}_{2}$-PEI were assigned to the vibration of $\mathrm{C}=\mathrm{O}$ (-CONH amide band I), $\mathrm{C}-\mathrm{N}$ (amide band II), and $\mathrm{N}-\mathrm{H}$ (amide band III) C-N stretch of amide, suggesting a covalent bonding of PEI to the 
epoxide ring $[21,28,33]$. The C-O-C peak of $\mathrm{AC}-\mathrm{Fe}_{3} \mathrm{O}_{4}-\mathrm{SiO}_{2}$ at $1054.45 \mathrm{~cm}^{-1}$ was replaced by two peaks of the primary amine groups of the PEI at $1092-1030 \mathrm{~cm}^{-1}$, representing the stretching $\mathrm{N}-\mathrm{H}$ bends [28]. This suggested that the C-O-C functionality participated in the bonding of PEI to AC- $\mathrm{Fe}_{3} \mathrm{O}_{4}-\mathrm{SiO}_{2}$ [28]. Moreover, these findings revealed that the PEI was bonded on the $\mathrm{SiO}_{2}$ [32]. Although the peak of the $\mathrm{SiO}_{2}$ was replaced by the amine groups, the symmetric shifted Si-O-Si peak at $759.24 \mathrm{~cm}^{-1}$ was still visible together with the vibrating stretches of the $\mathrm{Fe}-\mathrm{O}$ at $559.94 \mathrm{~cm}^{-1}$ [21].

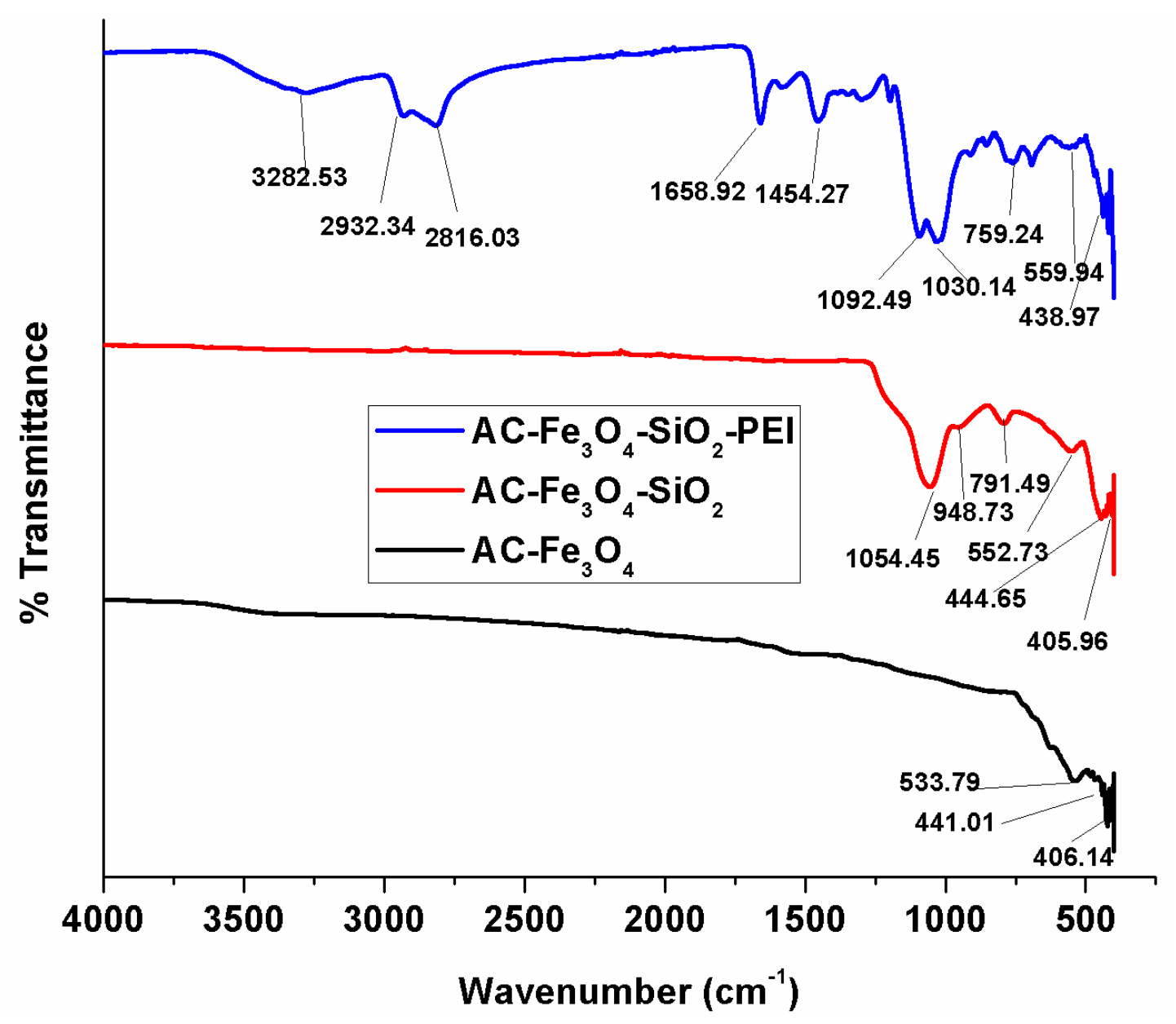

Figure 1. FTIR spectra of $\mathrm{AC}-\mathrm{Fe}_{3} \mathrm{O}_{4}, \mathrm{AC}-\mathrm{Fe}_{3} \mathrm{O}_{4}-\mathrm{SiO}_{2}$, and $\mathrm{AC}-\mathrm{Fe}_{3} \mathrm{O}_{4}-\mathrm{SiO}_{2}$-PEI.

The elemental composition and specific surface area $\left(\mathrm{S}_{\mathrm{BET}}\right)$ analyses of the prepared adsorbents together with that of $\mathrm{AC}$ reference material are shown in Table 1 . The inclusion of $\mathrm{Fe}_{3} \mathrm{O}_{4}$ nanoparticles on $\mathrm{AC}$ lowered the $\% \mathrm{C}$ from $83.27 \%$ to $44.03 \%$ and the $\mathrm{S}_{\mathrm{BET}}$ surface area decreased from 546 to $386.89 \mathrm{~m}^{2} / \mathrm{g}$. The decrease in $\% \mathrm{C}$ was attributed to the presence of $\mathrm{Fe}$, which is a much heavier atom than $\mathrm{C}$, while the surface area reduction was probably due to the filling of $\mathrm{AC}$ pores by $\mathrm{Fe}_{3} \mathrm{O}_{4}$ nanoparticles or surface coverage through the formation of a semi-permeable layer of $\mathrm{Fe}_{3} \mathrm{O}_{4}$ on the $\mathrm{AC}$ surface. The atomic percent of $\mathrm{C}$ and $\mathrm{H}$ increased upon functionalization of $\mathrm{AC}-\mathrm{Fe}_{3} \mathrm{O}_{4}$ by silica due to the attachment of $\mathrm{CH}_{3} \mathrm{CH}_{2}$ - branches of the TEOS, but the surface area decreased to $234.51 \mathrm{~m}^{2} / \mathrm{g}$. The $\%$ residual increased as functionalization occurred implying that other components except those of $\mathrm{C}, \mathrm{H}, \mathrm{N}$, and $\mathrm{S}$ were present. The inclusion of an impervious layer of PEI on $\mathrm{AC}-\mathrm{Fe}_{3} \mathrm{O}_{4}-\mathrm{SiO}_{2}$ drastically decreased the $\mathrm{BET}$ value from 234.51 to $0.15 \mathrm{~m}^{2} / \mathrm{g}$. Elsewhere, it was also observed that functionalization of $\mathrm{AC}$ with PEI led to a decrease in specific surface area from 942 to $32 \mathrm{~m}^{2} / \mathrm{g}$ due to surface passivation [34]. All the adsorbents had pore sizes ranging between 2 and $50 \mathrm{~nm}$, signifying that the adsorbents had a mesoporous character as per the IUPAC categorization of pore sizes. 
Table 1. Elemental analysis and surface characterization of adsorbents.

\begin{tabular}{|c|c|c|c|c|c|c|c|c|}
\hline \multirow[t]{2}{*}{ Adsorbents } & \multicolumn{5}{|c|}{ Elemental Analysis } & \multicolumn{3}{|c|}{ Surface Characterization } \\
\hline & $\% \mathrm{C}$ & $\% \mathbf{H}$ & $\% \mathbf{N}$ & $\% S$ & $\% \mathbf{R} *$ & $\begin{array}{l}\text { Surface Area } \\
\left(\mathrm{m}^{2} / \mathrm{g}\right)\end{array}$ & $\begin{array}{l}\text { Pore Volume } \\
\quad\left(\mathrm{cm}^{3} / \mathrm{g}\right)\end{array}$ & $\begin{array}{l}\text { Pore Size } \\
\text { (nm) }\end{array}$ \\
\hline $\mathrm{AC}$ & 83.27 & 1.53 & 0.50 & - & 14.70 & 546.00 & 0.354 & 2.59 \\
\hline $\mathrm{AC}-\mathrm{Fe}_{3} \mathrm{O}_{4}$ & 44.03 & 1.41 & 0.25 & $<0.1$ & 55.69 & 386.89 & 0.294 & 7.85 \\
\hline $\mathrm{AC}-\mathrm{Fe}_{3} \mathrm{O}_{4}-\mathrm{SiO}_{2}$ & 68.30 & 1.79 & 0.44 & $<0.1$ & 29.47 & 234.51 & 0.149 & 5.75 \\
\hline $\mathrm{AC}-\mathrm{Fe}_{3} \mathrm{O}_{4}-\mathrm{SiO}_{2}$-PEI & 38.50 & 6.71 & 3.00 & - & 57.75 & 0.15 & 0.267 & 26.48 \\
\hline
\end{tabular}

${ }^{*} \mathrm{R}=$ residual $(\mathrm{O}, \mathrm{Fe}, \mathrm{Si})$ calculated by difference.

The nitrogen adsorption-desorption plots are shown in Figure 2. These plots were used to determine the adsorption type and porosity structure of the adsorbent. $\mathrm{AC}-\mathrm{Fe}_{3} \mathrm{O}_{4}$ and $\mathrm{AC}-\mathrm{Fe}_{3} \mathrm{O}_{4}-\mathrm{SiO}_{2}$ exhibited similar-shaped graphs. The graphs were of Type II adsorption isotherms hinting at a monolayer or multi-layered adsorption process. The graphs seemed to run parallel to $\mathrm{P} / \mathrm{P}_{\mathrm{o}}$ at relative pressures below 0.9 , in particular the $\mathrm{AC}-\mathrm{Fe}_{3} \mathrm{O}_{4}-\mathrm{SiO}_{2}$ and $\mathrm{AC}-\mathrm{Fe}_{3} \mathrm{O}_{4}-\mathrm{SiO}_{2}$-PEI, and then manifested a hysterical loop which suggested the formation of a microporous structure. $\mathrm{AC}-\mathrm{Fe}_{3} \mathrm{O}_{4}-\mathrm{SiO}_{2}$-PEI demonstrated a Type IV adsorption which is associated with capillary condensation of the mesoporous structure. A sharp hysterical loop at relatively low pressures represents adsorption-desorption hysteresis and is most common in oxide gels and mesoporous carbon materials [15].

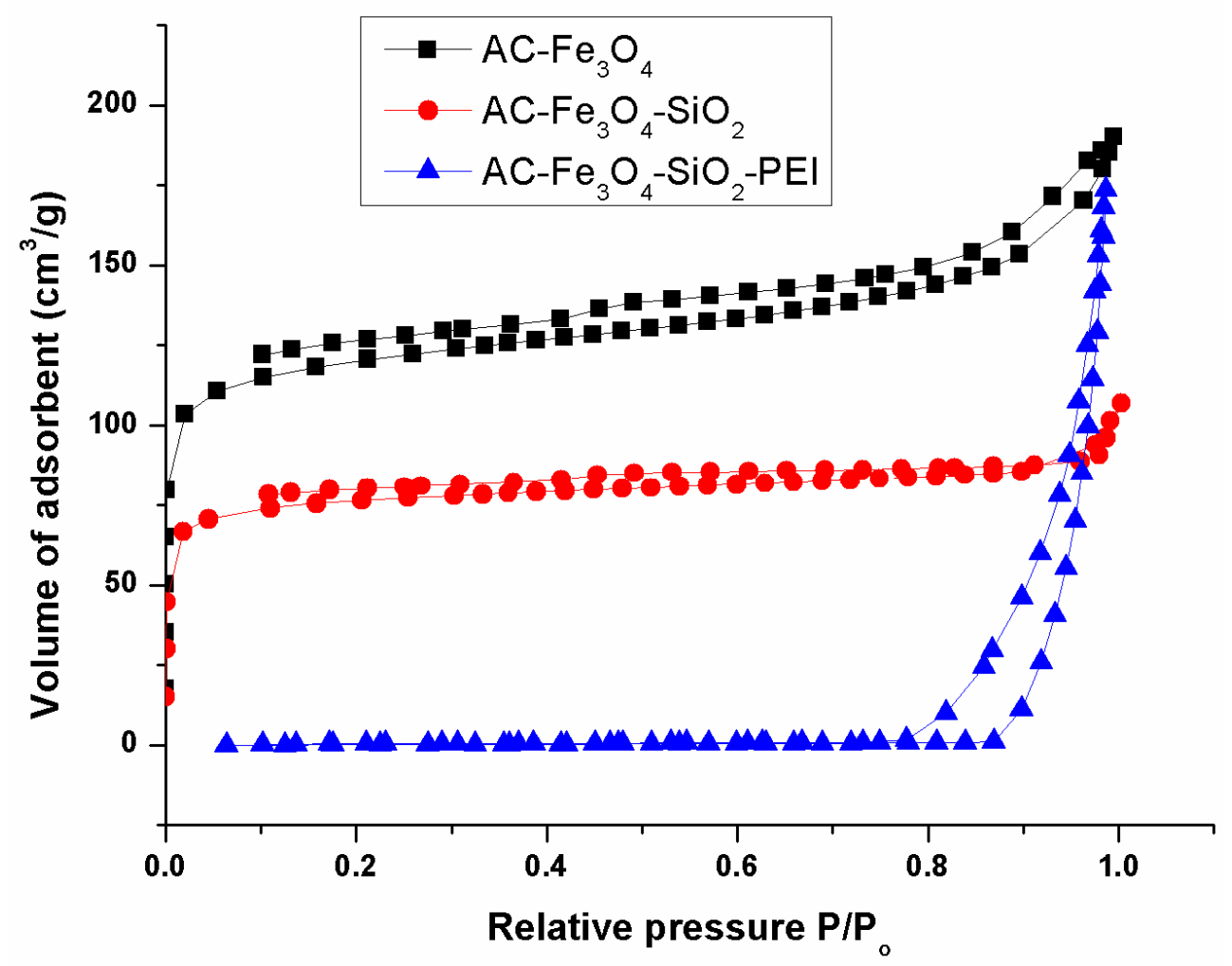

Figure 2. $\mathrm{N}_{2}$ adsorption/desorption isotherms of $\mathrm{AC}-\mathrm{Fe}_{3} \mathrm{O}_{4}, \mathrm{AC}-\mathrm{Fe}_{3} \mathrm{O}_{4}-\mathrm{SiO}_{2}$, and $\mathrm{AC}-\mathrm{Fe}_{3} \mathrm{O}_{4}-\mathrm{SiO}_{2}$-PEI.

The X-ray-diffraction patterns for $\mathrm{AC}-\mathrm{Fe}_{3} \mathrm{O}_{4}, \mathrm{AC}-\mathrm{Fe}_{3} \mathrm{O}_{4}-\mathrm{SiO}_{2}$, and $\mathrm{AC}-\mathrm{Fe}_{3} \mathrm{O}_{4}-\mathrm{SiO}_{2}-$ PEI are presented in Figure 3. AC- $-\mathrm{Fe}_{3} \mathrm{O}_{4}$ and $\mathrm{AC}-\mathrm{Fe}_{3} \mathrm{O}_{4}-\mathrm{SiO}_{2}$ exhibited six diffraction peaks at $2 \theta=30^{\circ}, 35^{\circ}, 43^{\circ}, 54^{\circ}, 57^{\circ}$, and $63^{\circ}$ which were related to $220,311,400,511$ and 440 crystal planes according to Bragg's reflection [16]. These diffraction peaks belong to the magnetite reference with a PDF card 19-0629 showing that $\mathrm{Fe}_{3} \mathrm{O}_{4}$ was successfully attached to the activated carbon [35]. The peak at $2 \theta$ of $35^{\circ}$ in $\mathrm{AC}-\mathrm{Fe}_{3} \mathrm{O}_{4}-\mathrm{SiO}_{2}-\mathrm{PEI}$ was related to Bragg's reflection of 311 for the magnetite. This shows that even though the surface of the 
AC was fully covered by the PEI, some Fe content was still present in the adsorbent. A large amorphous peak observed at $2 \theta=20^{\circ}$ in $\mathrm{AC}-\mathrm{Fe}_{3} \mathrm{O}_{4}-\mathrm{SiO}_{2}-\mathrm{PEI}$ was attributed to the amorphous structure of the PEI.

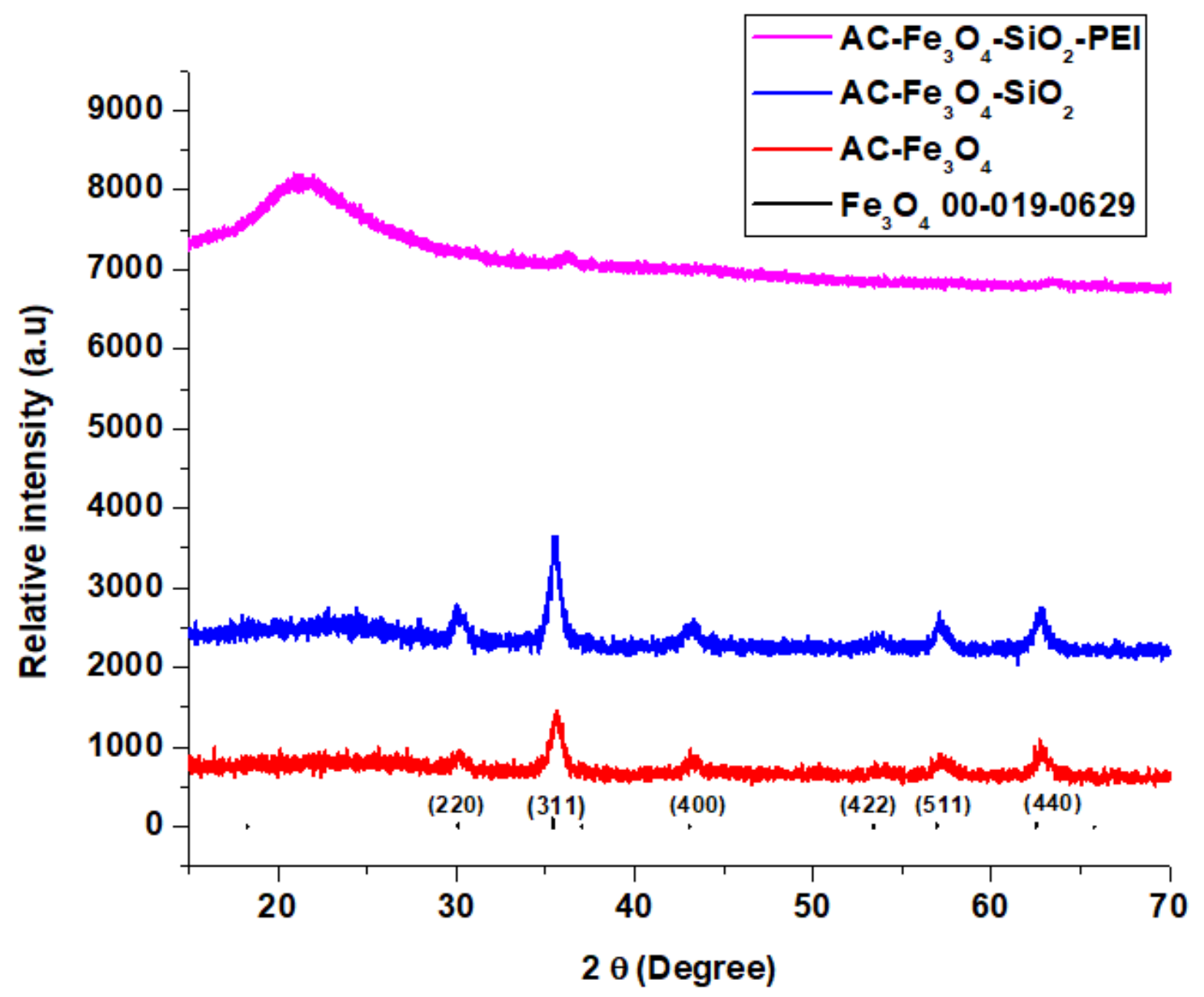

Figure 3. X-ray diffraction spectra of $\mathrm{AC}-\mathrm{Fe}_{3} \mathrm{O}_{4}, \mathrm{AC}-\mathrm{Fe}_{3} \mathrm{O}_{4}-\mathrm{SiO}_{2}$, and $\mathrm{AC}-\mathrm{Fe}_{3} \mathrm{O}_{4}-\mathrm{SiO}_{2}$-PEI.

The SEM, TEM, and EDS graphs were used to study the morphology and elemental content of the prepared adsorbents (Figure 4). In the SEM image of $\mathrm{AC}-\mathrm{Fe}_{3} \mathrm{O}_{4}$ shown in Figure $4 \mathrm{a}$, small white precipitates of the $\mathrm{Fe}_{3} \mathrm{O}_{4}$ are observed as deposits in the large spherical pores of the AC. The EDS spectrum of AC- $\mathrm{Fe}_{3} \mathrm{O}_{4}$ in Figure $4 \mathrm{~b}$ depicts the adsorbent to contain $\mathrm{C}, \mathrm{Fe}$, and $\mathrm{O}$ atoms in relative abundances of $62.2,20.76$, and $16.11 \mathrm{wt} . \%$, respectively, among other things. The amorphousness observed in the SEM image of AC$\mathrm{Fe}_{3} \mathrm{O}_{4}-\mathrm{SiO}_{2}$ in Figure $4 \mathrm{c}$ was attributed to the deposition of silica to the $\mathrm{AC}-\mathrm{Fe}_{3} \mathrm{O}_{4}$ surface, and this was confirmed by the elemental contents shown in the EDS spectrum (12.7 wt. $\% \mathrm{Si}$ and $17.1 \mathrm{wt} . \% \mathrm{Fe}$ ) (Figure 4d). The increase in $\mathrm{O}$ atom abundance from 16.11 to $25.4 \mathrm{wt} . \%$ also corroborates the presence of $\mathrm{SiO}_{2}$. Figure 4e,f depict the SEM and EDS spectral data of $\mathrm{AC}-\mathrm{Fe}_{3} \mathrm{O}_{4}-\mathrm{SiO}_{2}$-PEI. Irregular-shaped particles with smooth surfaces attributable to the gelatinous character of the PEI were observed. The EDS data (Figure $4 \mathrm{f}$ ) confirmed the presence of $\mathrm{C}(51.0 \mathrm{wt.} \%)$, Fe (1.7 wt.\%), and $\mathrm{Si}(12.1 \mathrm{wt} . \%)$ which formed the backbone of the adsorbent material. The $\mathrm{C}$ and $\mathrm{O}$ percent increased to $51.0 \mathrm{wt}$. \% and $34.3 \mathrm{wt} . \%$, respectively, signifying the presence of alkyl branched chains of PEI. The decrease in Fe content from $17.1 \mathrm{wt} . \%$ to $1.7 \mathrm{wt} . \%$ was attributed to leaching and oxidization of $\mathrm{Fe}_{3} \mathrm{O}_{4}$ as functionalization occurred. No $\mathrm{N}$ content was recorded on the EDS probably due to its lower atomic mass. The TEM images of $\mathrm{AC}-\mathrm{Fe}_{3} \mathrm{O}_{4}, \mathrm{AC}-\mathrm{Fe}_{3} \mathrm{O}_{4}-\mathrm{SiO}_{2}$, and $\mathrm{AC}-\mathrm{Fe}_{3} \mathrm{O}_{4}-$ $\mathrm{SiO}_{2}$-PEI are illustrated in Figure 5a-c. The darker shades in TEM were attributed to the presence of $\mathrm{Fe}_{3} \mathrm{O}_{4}$ while the lighter ones were due to $\mathrm{AC}$ backbone and silica. 

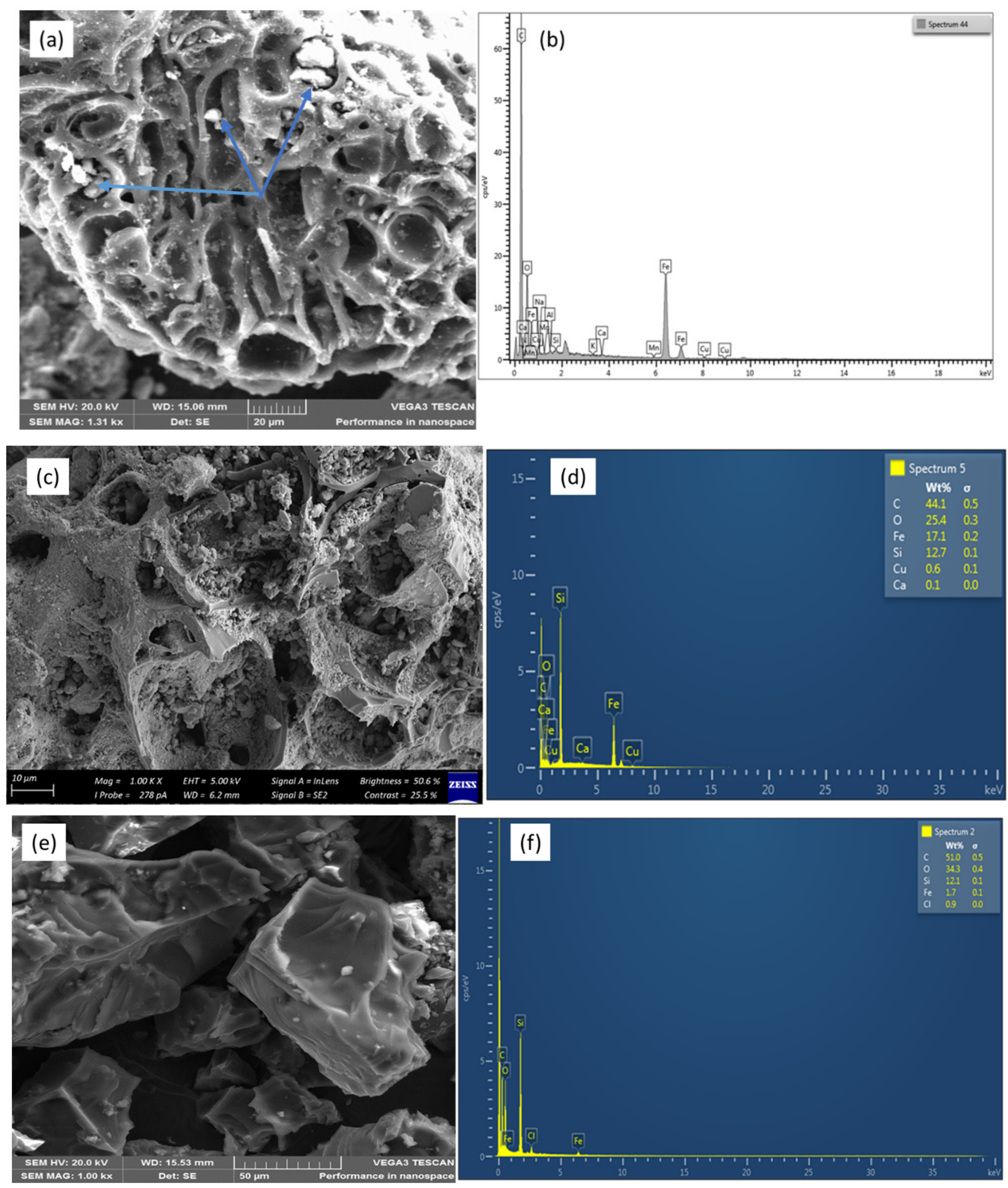

Figure 4. (a) SEM and (b) EDS of AC- $\mathrm{Fe}_{3} \mathrm{O}_{4}$, (c) SEM and (d) EDS of AC- $-\mathrm{Fe}_{3} \mathrm{O}_{4}-\mathrm{SiO}_{2}$ : (e) $\mathrm{SEM}$ and (f) EDS of AC-Fe $\mathrm{F}_{3} \mathrm{O}_{4}-\mathrm{SiO}_{2}-\mathrm{PEI}$. 

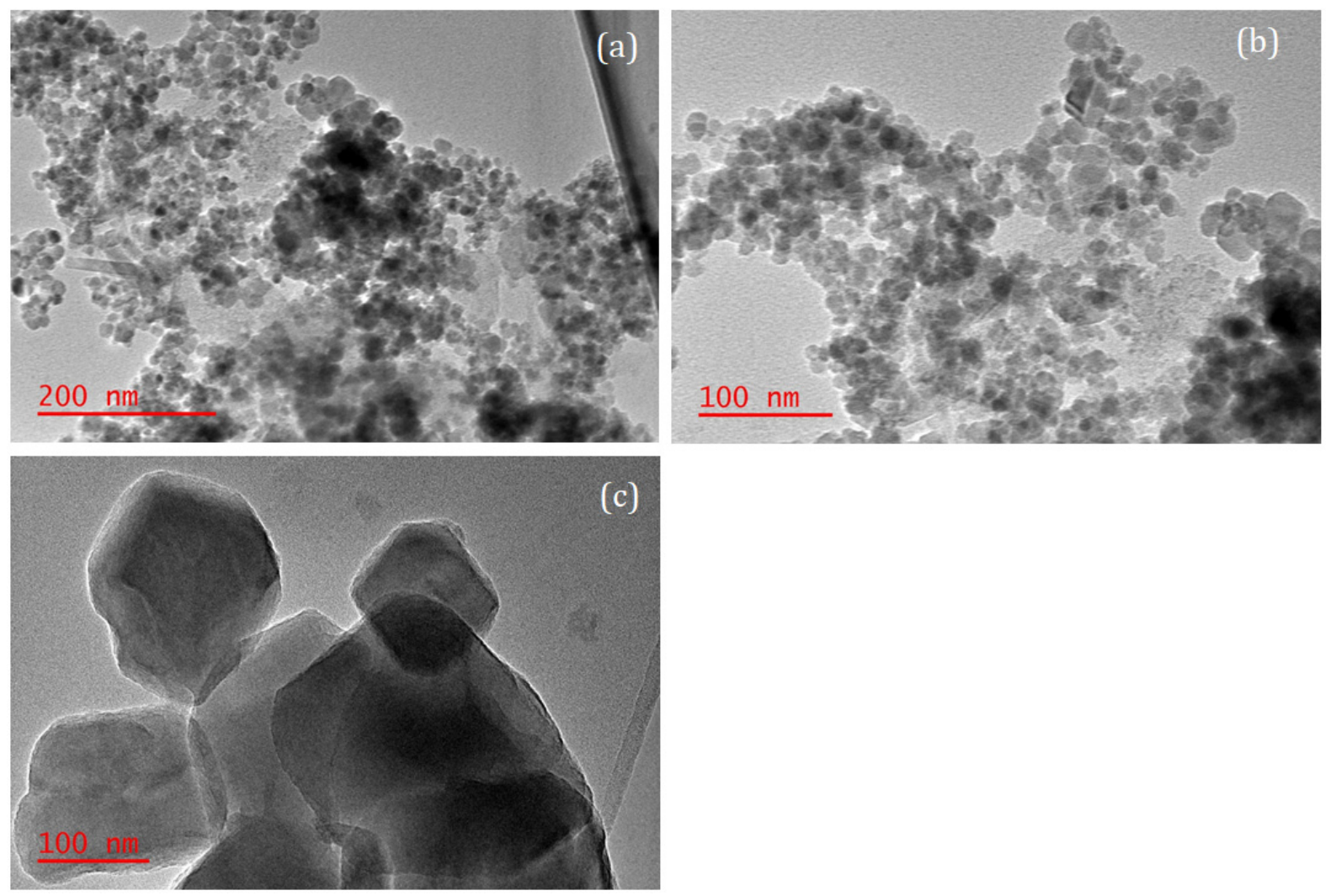

(c)

Figure 5. TEM images of $\mathrm{AC}-\mathrm{Fe}_{3} \mathrm{O}_{4}(\mathbf{a}), \mathrm{AC}-\mathrm{Fe}_{3} \mathrm{O}_{4}-\mathrm{SiO}_{2}(\mathbf{b})$, and $\mathrm{AC}-\mathrm{Fe}_{3} \mathrm{O}_{4}-\mathrm{SiO}_{2}-\mathrm{PEI}$ (c).

Thermogravimetric analysis (TGA) and derivative thermogravimetric analysis (DTA) were used to study the thermal stability and decomposition stages of $\mathrm{AC}-\mathrm{Fe}_{3} \mathrm{O}_{4}, \mathrm{AC}-\mathrm{Fe}_{3} \mathrm{O}_{4}$ $\mathrm{SiO}_{2}$, and $\mathrm{AC}-\mathrm{Fe}_{3} \mathrm{O}_{4}-\mathrm{SiO}_{2}$-PEI. The results are demonstrated in Figure 6. The decomposition curves exhibit different patterns as distinctly shown by the derivatives curves. However, some commonalities were observed, such as the decomposition stage taking place between 40 and $100{ }^{\circ} \mathrm{C}$ credited to moisture loss. This was quantified to 5, 5, and $10 \%$ weight loss for $\mathrm{AC}-\mathrm{Fe}_{3} \mathrm{O}_{4}, \mathrm{AC}-\mathrm{Fe}_{3} \mathrm{O}_{4}-\mathrm{SiO}_{2}$, and $\mathrm{AC}-\mathrm{Fe}_{3} \mathrm{O}_{4}-\mathrm{SiO}_{2}-\mathrm{PEI}$, respectively. The second weight loss was observed between 100 and $800{ }^{\circ} \mathrm{C}$ with $5 \%$ weight loss for $\mathrm{AC}-\mathrm{Fe}_{3} \mathrm{O}_{4}$, between 100 and $300{ }^{\circ} \mathrm{C}$ for $\mathrm{AC}-\mathrm{Fe}_{3} \mathrm{O}_{4}-\mathrm{SiO}_{2}$ with $15 \%$ weight loss, and lastly between 300 and $600{ }^{\circ} \mathrm{C}$ for AC- $\mathrm{Fe}_{3} \mathrm{O}_{4}-\mathrm{SiO}_{2}$-PEI with $40 \%$ weight loss. This stage was attributed to the loss of volatile compounds such as $\mathrm{CO}_{2}, \mathrm{CH}_{4}, \mathrm{CO}$, and decomposition of adsorbents [36]. More of this weight loss was expressed with $\mathrm{AC}-\mathrm{Fe}_{3} \mathrm{O}_{4}-\mathrm{SiO}_{2}$ and $\mathrm{AC}-\mathrm{Fe}_{3} \mathrm{O}_{4}-\mathrm{SiO}_{2}-\mathrm{PEI}$ as compared to $\mathrm{AC}-\mathrm{Fe}_{3} \mathrm{O}_{4}$. This was attributed to longer chains of $\mathrm{CH}_{3} \mathrm{CH}_{2}$ - of the TEOS and those of the branched PEI. The last decomposition stage was attributed to the loss of lignin of the adsorbent which was more pronounced with $\mathrm{AC}-\mathrm{Fe}_{3} \mathrm{O}_{4}-\mathrm{SiO}_{2}$ and $\mathrm{AC}-\mathrm{Fe}_{3} \mathrm{O}_{4}-\mathrm{SiO}_{2}-\mathrm{PEI}$ than with $\mathrm{AC}-\mathrm{Fe}_{3} \mathrm{O}_{4}$. Less weight loss observed by $\mathrm{AC}-\mathrm{Fe}_{3} \mathrm{O}_{4}$ was attributed to the thermal stability of the $\mathrm{Fe}_{3} \mathrm{O}_{4}$ nanoparticles. 


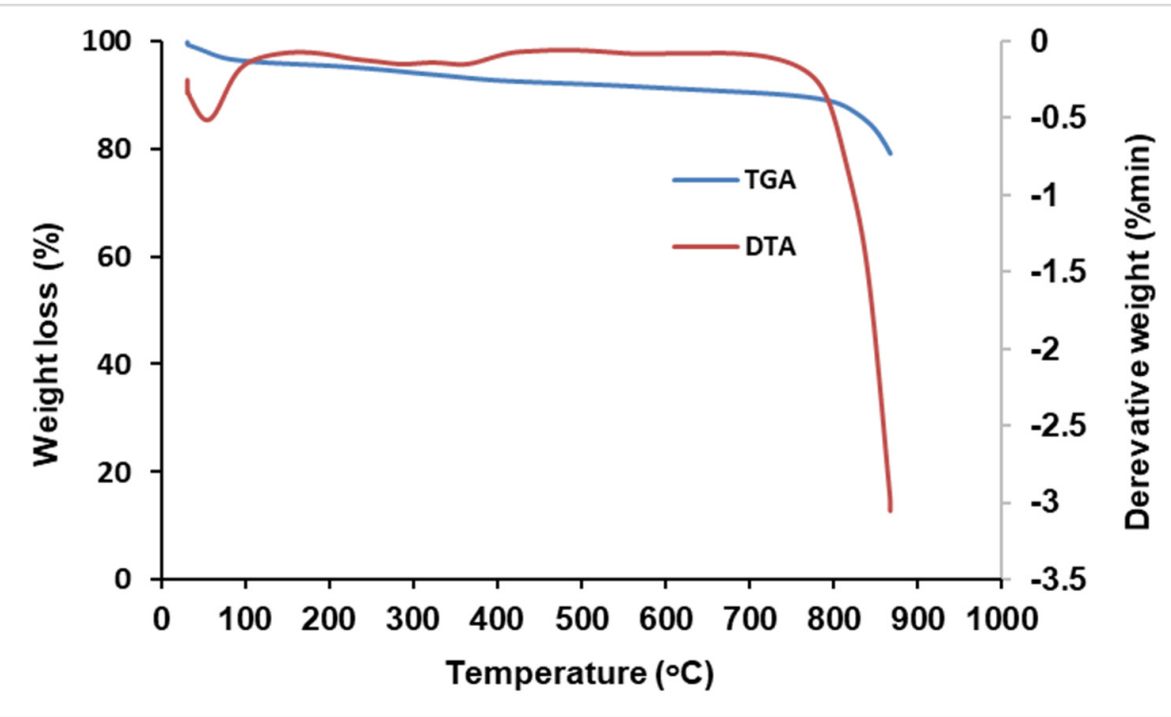

(a)

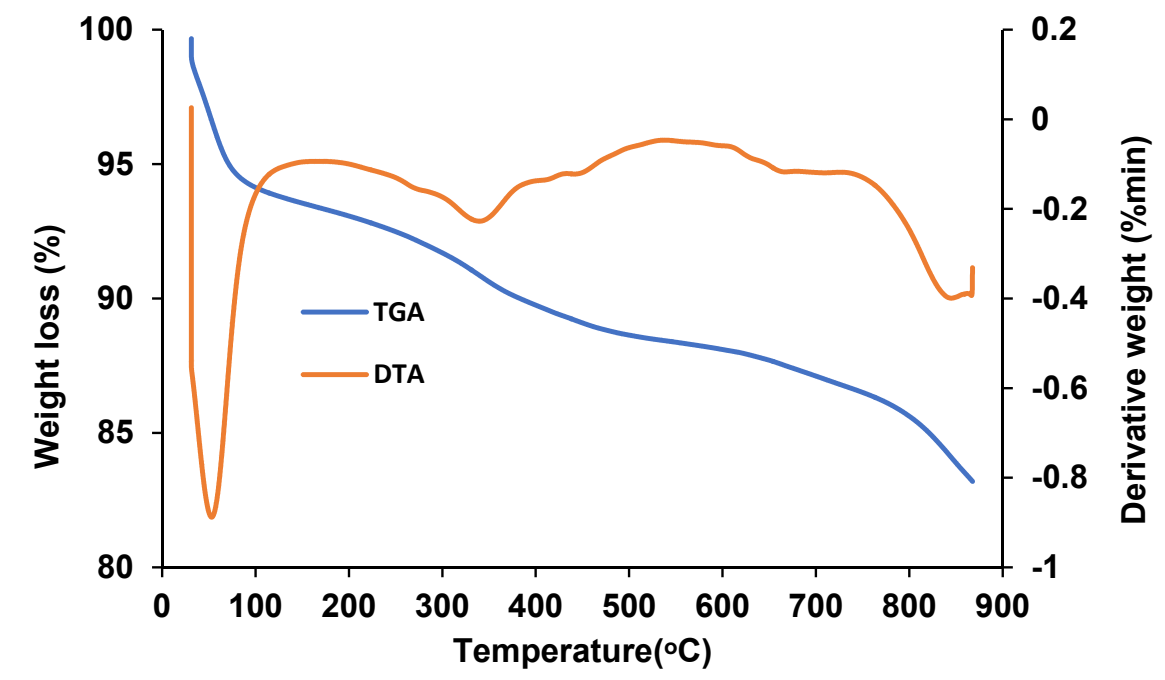

(b)

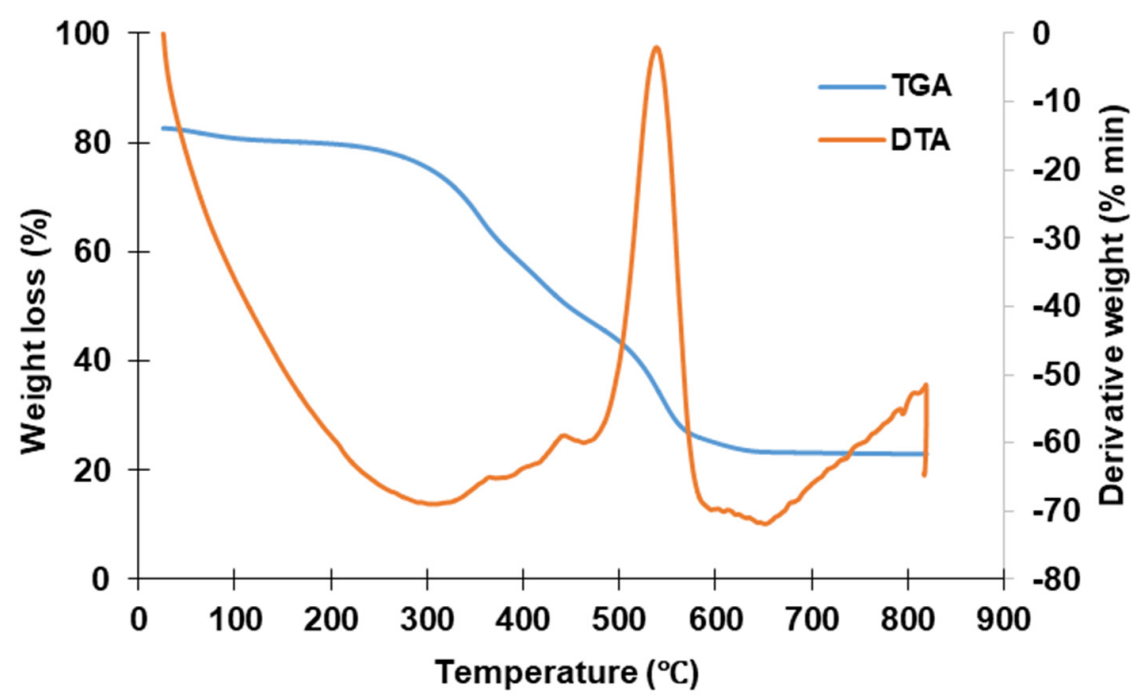

(c)

Figure 6. TGA and DTA of $\mathrm{AC}-\mathrm{Fe}_{3} \mathrm{O}_{4}(\mathbf{a}), \mathrm{AC}-\mathrm{Fe}_{3} \mathrm{O}_{4}-\mathrm{SiO}_{2}(\mathbf{b})$, and $\mathrm{AC}-\mathrm{Fe}_{3} \mathrm{O}_{4}-\mathrm{SiO}_{2}-\mathrm{PEI}$ (c). 


\subsection{Influence of Solution $\mathrm{pH}$ on Adsorption of $\mathrm{Cr}(\mathrm{VI})$}

The zeta potential data of $\mathrm{AC}-\mathrm{Fe}_{3} \mathrm{O}_{4}, \mathrm{AC}-\mathrm{Fe}_{3} \mathrm{O}_{4}-\mathrm{SiO}_{2}$, and $\mathrm{AC}-\mathrm{Fe}_{3} \mathrm{O}_{4}-\mathrm{SiO}_{2}$-PEI measured at different solution $\mathrm{pH}$ values are illustrated in Figure 7. The isoelectric point (IEP) can be determined from the graph as the $\mathrm{pH}$ point at which the surface charge of the adsorbent is zero or rather surface had electrical neutrality. It can be observed in Figure 7 that the zeta potential $(\mathrm{mV})$ magnitude decreased with increasing solution $\mathrm{pH}$ for all adsorbents. At $\mathrm{pH}$ values below the IEP, the surface of the adsorbent is mostly positively charged and above IEP the surface is negatively charged $[5,7,37]$. The $\mathrm{pH}_{\text {IEP }}$ of $\mathrm{AC}-\mathrm{Fe}_{3} \mathrm{O}_{4}$, $\mathrm{AC}-\mathrm{Fe}_{3} \mathrm{O}_{4}-\mathrm{SiO}_{2}$, and $\mathrm{AC}-\mathrm{Fe}_{3} \mathrm{O}_{4}-\mathrm{SiO}_{2}$-PEI was found to be 4.95, 3.53, and 11.69, respectively. The high IEP ( $\mathrm{pH}$ 11.69) observed for $\mathrm{AC}-\mathrm{Fe}_{3} \mathrm{O}_{4}-\mathrm{SiO}_{2}-\mathrm{PEI}$ was attributed to the cationic characteristic of PEI $[38,39]$.

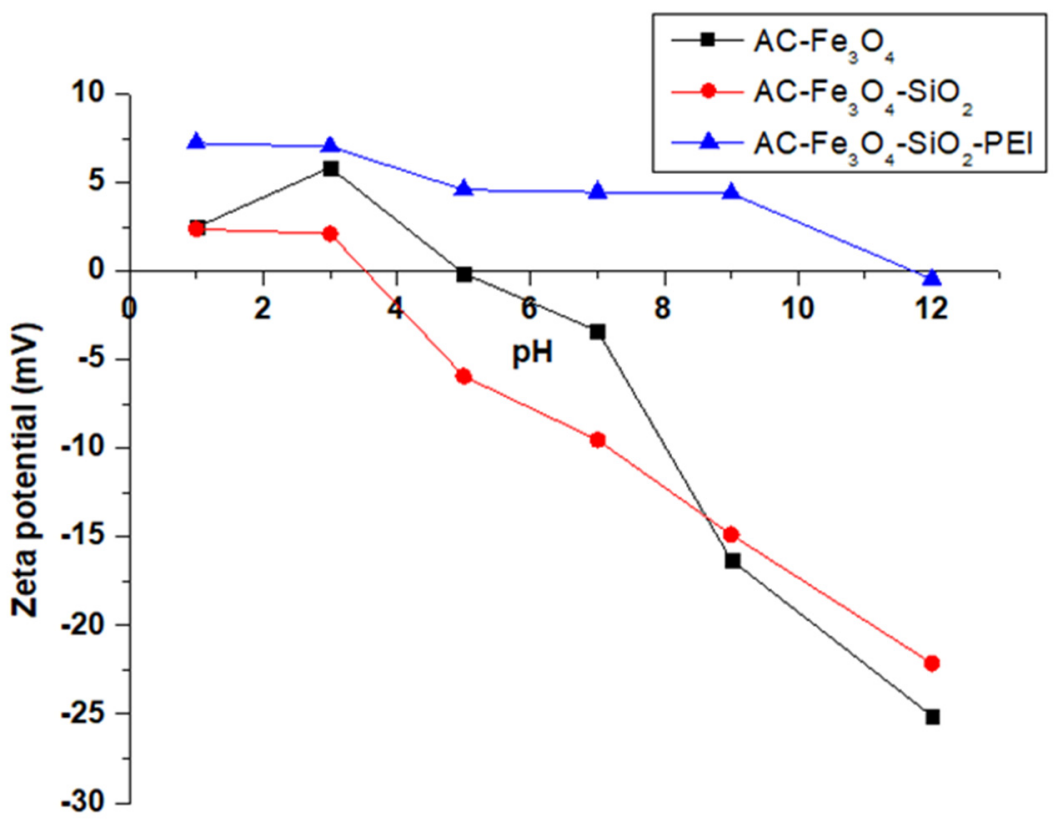

Figure 7. Zeta potential of $\mathrm{AC}-\mathrm{Fe}_{3} \mathrm{O}_{4}, \mathrm{AC}-\mathrm{Fe}_{3} \mathrm{O}_{4}-\mathrm{SiO}_{2}$ and $\mathrm{AC}-\mathrm{Fe}_{3} \mathrm{O}_{4}-\mathrm{SiO}_{2}$-PEI.

The $\mathrm{pH}$ of a solution affects the surface chemistry of adsorbents, ionization, and bioavailability of adsorbates [25,40]. Hence, the investigation of its influence on adsorption is crucial. The influence of solution $\mathrm{pH}$ was investigated over the range of $\mathrm{pH} 1-12$ and the result depicting the adsorption capacities against the $\mathrm{pH}$ is referred to in Figure 8a-c. All adsorbents exhibited a similar trend where the adsorption capacity of $\mathrm{Cr}(\mathrm{VI})$ decreased as the $\mathrm{pH}$ of the solution increased. The highest removal efficiencies were obtained between $\mathrm{pH} 1$ and 3 for all three adsorbents. Explicitly, the optimum $\mathrm{pH}$ for $\mathrm{AC}-\mathrm{Fe}_{3} \mathrm{O}_{4}(4.75 \mathrm{mg} / \mathrm{g})$ was $\mathrm{pH} 3$, and for both $\mathrm{AC}-\mathrm{Fe}_{3} \mathrm{O}_{4}-\mathrm{SiO}_{2}(4.47 \mathrm{mg} / \mathrm{g})$ and $\mathrm{AC}-\mathrm{Fe}_{3} \mathrm{O}_{4}-\mathrm{SiO}_{2}-\mathrm{PEI}(3.63 \mathrm{mg} / \mathrm{g})$, it was $\mathrm{pH}$ 1. The low removal efficiencies at high $\mathrm{pH}$ levels were attributed to forces of repulsion between negative sites on the adsorbent's surface and the anionic $\mathrm{Cr}(\mathrm{VI})$ ions in solutions. The negative sites on adsorbent surfaces are caused by the presence of a high concentration of $\mathrm{OH}^{-}$ions resulting from the $\mathrm{NaOH}$ solution used for the $\mathrm{pH}$ adjustments. In the case of $\mathrm{AC}-\mathrm{Fe}_{3} \mathrm{O}_{4}-\mathrm{SiO}_{2}$-PEI with high IEP at $\mathrm{pH} 11.69$, the repulsion of $\mathrm{Cr}(\mathrm{VI})$ at high $\mathrm{pHs}$ could be due to the preferential binding of $\mathrm{OH}^{-}$groups to the cationic sites of adsorbents. 


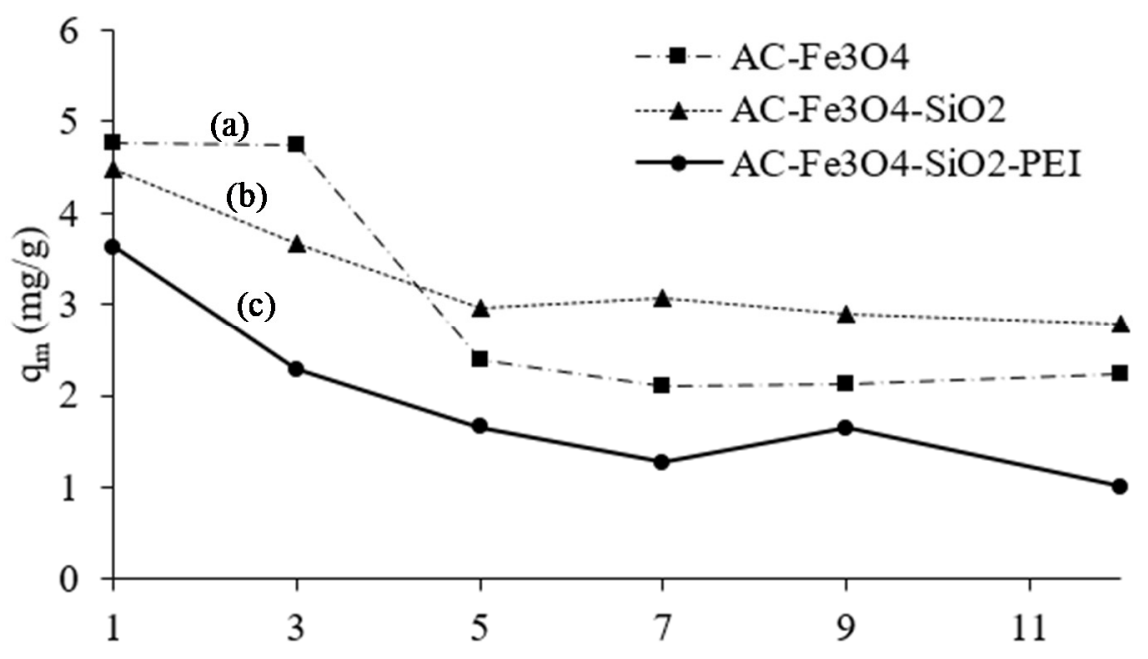

Figure 8. Effect of solution $\mathrm{pH}$ on the adsorption of $\mathrm{Cr}(\mathrm{VI})$ by $\mathrm{AC}-\mathrm{Fe}_{3} \mathrm{O}_{4}(\mathbf{a}), \mathrm{AC}^{-} \mathrm{Fe}_{3} \mathrm{O}_{4}-\mathrm{SiO}_{2}$ (b), and $\mathrm{AC}-\mathrm{Fe}_{3} \mathrm{O}_{4}-\mathrm{SiO}_{2}-\mathrm{PEI}$ (c). (conditions: $8 \mathrm{mg} / \mathrm{L}$ initial concentration 60 min contact time, $0.05 \mathrm{~g}$ adsorbent mass, $25{ }^{\circ} \mathrm{C}$ temperature and $30 \mathrm{~mL}$ solution volume).

The stability of the oxyanion character of $\mathrm{Cr}(\mathrm{VI})$ in solution is dependent on the solution $\mathrm{pH}$, thus, the predominating species in acidic media ( $\mathrm{pH} 1-5)$ is mostly $\mathrm{HCrO}_{4}{ }^{-}$, which is yielded by the hydrolysis of the dichromate ion $\left(\mathrm{Cr}_{2} \mathrm{O}_{7}{ }^{2-}\right)$ [25]. The oxyanions $\left(\mathrm{HCrO}_{4}{ }^{-}\right.$, $\mathrm{CrO}_{4}{ }^{2-}$ and $\mathrm{Cr}_{2} \mathrm{O}_{7}{ }^{2-}$ ) at acidic conditions turn to become electrostatically attracted to the positively charged surface functional groups of the adsorbent [41]. The positive surface functional groups may be the results of protonation of $\mathrm{NH}_{2}, \mathrm{COOH}, \mathrm{OH}$ - functional groups on the surface of the adsorbents to form $\mathrm{NH}_{3}{ }^{+}, \mathrm{COOH}^{2+}, \mathrm{OH}^{+}[36,42]$. Because these functional groups are rich in electrons, it is possible that during $\mathrm{Cr}(\mathrm{VI})$ adsorption, some portion of the $\mathrm{Cr}(\mathrm{VI})$ is transformed to $\mathrm{Cr}(\mathrm{III})$ through receiving electrons from, for example, $\mathrm{NH}_{2}$. In addition to the electrostatic attraction of $\mathrm{Cr}(\mathrm{VI})$ to the positively charged functional groups of the adsorbents at low acidic solutions, the reduction of $\mathrm{Cr}(\mathrm{VI})$ to $\mathrm{Cr}(\mathrm{III})$ due to the presence of electron-donating groups such as $\mathrm{OH}, \mathrm{NH}_{2}, \mathrm{SH}, \mathrm{COOH}$, and the oxidation of $\mathrm{Fe}^{2+}$ to $\mathrm{Fe}^{3+}$ are the other possible mechanisms for $\mathrm{Cr}(\mathrm{VI})$ removal by the prepared adsorbents [43]. The higher removal exhibited by AC- $\mathrm{Fe}_{3} \mathrm{O}_{4}$ compared to $\mathrm{AC}-\mathrm{Fe}_{3} \mathrm{O}_{4}-\mathrm{SiO}_{2}$ and $\mathrm{AC}-\mathrm{Fe}_{3} \mathrm{O}_{4}-\mathrm{SiO}_{2}$-PEI at acidic conditions could be attributed to the effects of adsorption and reduction of $\mathrm{Cr}(\mathrm{VI})$ to $\mathrm{Cr}(\mathrm{III})$ by $\mathrm{Fe}^{2+}$ ions on the surface of $\mathrm{AC}-\mathrm{Fe}_{3} \mathrm{O}_{4}[37,44]$. The same can be said of silica-containing adsorbent $\left(\mathrm{AC}-\mathrm{Fe}_{3} \mathrm{O}_{4}-\mathrm{SiO}_{2}\right)$. The presence of PEI could enhance the repulsion of $\mathrm{Cr}(\mathrm{VI})$ due to hydrophobicity of PEI, hence low adsorption. At basic $\mathrm{pH}$ conditions, the amino groups of the PEI may attract the $\mathrm{OH}^{-}$through hydrogen bonding $\left(\mathrm{R}-\mathrm{NH}_{2}-\mathrm{OH}^{-}\right)$, thus rendering the surface of adsorbent more electronegative, resulting in the repulsion of chromate ions and less adsorption effectiveness [42]. Moreover, the competition for adsorption sites between $\mathrm{OH}^{-}$and $\mathrm{CrO}_{4}{ }^{2-}$ at higher $\mathrm{pH}(\mathrm{pH}>6)$ has been reported by numerous researchers $[7,40,45]$. From $\mathrm{pH} 4$ onwards, $\mathrm{AC}-\mathrm{Fe}_{3} \mathrm{O}_{4}$ appears to have inferior performance compared to $\mathrm{AC}-\mathrm{Fe}_{3} \mathrm{O}_{4}-\mathrm{SiO}_{2}$, probably due to preferential binding of $\mathrm{OH}^{-}$by the exposed $\mathrm{Fe}^{2+} / \mathrm{Fe}^{3+}$ ions on $\mathrm{AC}-\mathrm{Fe}_{3} \mathrm{O}_{4}$.

\subsection{Adsorption Isotherms}

The equilibrium sorption data of $\mathrm{Cr}(\mathrm{VI})$ on $\mathrm{AC}-\mathrm{Fe}_{3} \mathrm{O}_{4}$ at $45{ }^{\circ} \mathrm{C}, \mathrm{AC}-\mathrm{Fe}_{3} \mathrm{O}_{4}-\mathrm{SiO}_{2}$ at $45^{\circ} \mathrm{C}$, and $\mathrm{AC}-\mathrm{Fe}_{3} \mathrm{O}_{4}-\mathrm{SiO}_{2}$-PEI at $45^{\circ} \mathrm{C}$ were fitted into Langmuir and Freundlich isotherm models to infer the type of interactions between the adsorbate and the adsorbents. The results are illustrated in Figure 9 and further summarized in Table 2. In Figure 9a the approximation line of Langmuir was closer to the experimental data points as compared to the Freundlich estimation. The coefficient of determination $\left(R^{2}\right)$, residual standard error (RSE), and the adsorption capacity $\left(q_{m}\right)$ were used to infer which isotherm model best fitted the results. The $\mathrm{R}^{2}$ value for $\mathrm{AC}-\mathrm{Fe}_{3} \mathrm{O}_{4}$ was 0.828 in Langmuir and 0.737 in Freundlich. 
Similarly, the RSE values were 0.172 and 0.263 in Langmuir and Freundlich models, respectively. In this regard, the higher $\mathrm{R}^{2}$ value and lower RSE in Langmuir concurred with the visual observation that the data were best described by a monolayer, adsorption phenomenon of Langmuir. Additionally, $\mathrm{AC}-\mathrm{Fe}_{3} \mathrm{O}_{4}-\mathrm{SiO}_{2}$ data fitted to the Langmuir model better using the same reasoning applied above. In addition, the experimental $\left(q_{e}\right)$ and estimated $\left(q_{m}\right)$ adsorption capacity values for $\mathrm{AC}-\mathrm{Fe}_{3} \mathrm{O}_{4}-\mathrm{SiO}_{2}$ were closer to each other for each respective adsorbent. However, the data for $\mathrm{AC}-\mathrm{Fe}_{3} \mathrm{O}_{4}-\mathrm{SiO}_{2}-\mathrm{PEI}$ seemed to follow a different trend, as depicted by its better fitting to Freundlich $\left(R^{2}=0.957\right.$; low RSE of 0.043), which suggests the complex adsorption of $\mathrm{Cr}(\mathrm{VI})$ through a multilayer process.
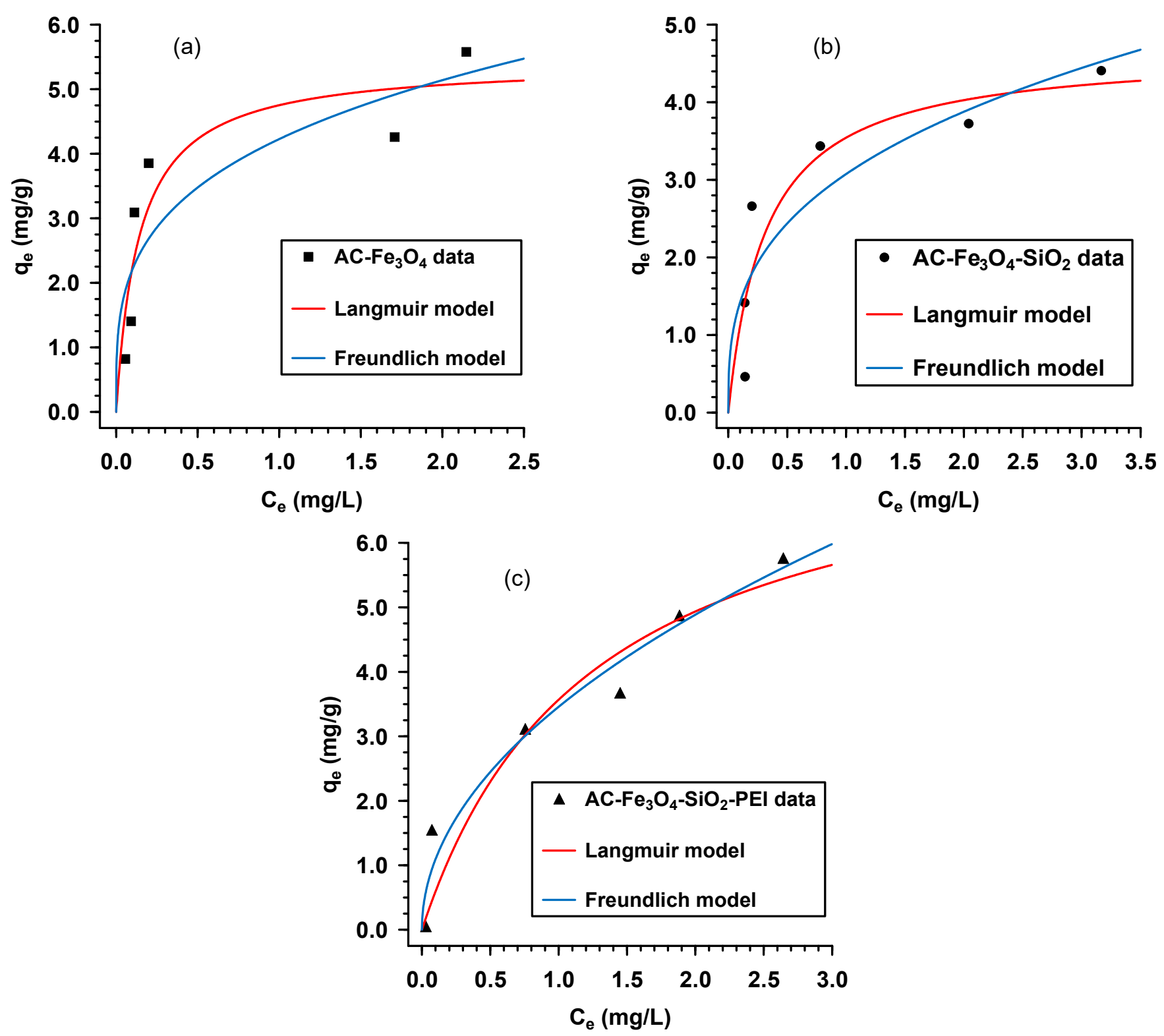

Figure 9. Isotherm modeling for the adsorption of $\mathrm{Cr}(\mathrm{VI})$ by $\mathrm{AC}-\mathrm{Fe}_{3} \mathrm{O}_{4}(\mathbf{a}), \mathrm{AC}-\mathrm{Fe}_{3} \mathrm{O}_{4}-\mathrm{SiO}_{2}(\mathbf{b})$, and $\mathrm{AC}-\mathrm{Fe} \mathrm{O}_{4}-\mathrm{SiO} \mathrm{O}_{2}-\mathrm{PEI}(\mathbf{c})$ at $45^{\circ} \mathrm{C}$. 
Table 2. The Freundlich and Langmuir adsorption isotherm parameters at $45^{\circ} \mathrm{C}$.

\begin{tabular}{|c|c|c|c|c|}
\hline Isotherms & Parameters & $\mathrm{AC}-\mathrm{Fe}_{3} \mathrm{O}_{4}$ & $\mathrm{AC}-\mathrm{Fe}_{3} \mathrm{O}_{4}-\mathrm{SiO}_{2}$ & $\mathrm{AC}-\mathrm{Fe}_{3} \mathrm{O}_{4}-\mathrm{SiO}_{2}$-PEI \\
\hline \multirow{4}{*}{ Langmuir isotherm } & $q_{m L}(\mathrm{mg} / \mathrm{g})$ & 5.43 & 4.67 & 8.00 \\
\hline & $b(\mathrm{~L} / \mathrm{mg})$ & 7.07 & 3.16 & 0.80 \\
\hline & $\mathrm{R}^{2}$ & 0.828 & 0.837 & 0.921 \\
\hline & RSE & 0.172 & 0.163 & 0.079 \\
\hline \multirow{4}{*}{ Freundlich isotherm } & $n$ & 3.55 & 2.99 & 2.00 \\
\hline & $K_{F}(\mathrm{mg} / \mathrm{g})(\mathrm{mg} / \mathrm{L})^{-1 / n}$ & 4.23 & 3.07 & 3.46 \\
\hline & $\mathrm{R}^{2}$ & 0.737 & 0.778 & 0.957 \\
\hline & RSE & 0.263 & 0.222 & 0.043 \\
\hline \multirow{4}{*}{$\begin{array}{l}\text { Dubinin-Radushkevich } \\
\text { isotherm }\end{array}$} & $q_{m D R}(\mathrm{mg} / \mathrm{g})$ & 5.23 & 4.22 & 4.72 \\
\hline & $K_{D R}\left(\mathrm{~mol}^{2} / \mathrm{kJ}^{2}\right)$ & 0.02 & 0.04 & 0.03 \\
\hline & $\mathrm{R}^{2}$ & 0.840 & 0.850 & 0.852 \\
\hline & RSE & 0.160 & 0.150 & 0.148 \\
\hline
\end{tabular}

\subsection{Adsorption Kinetics}

Pseudo-first-order (PFO) (Equation (6)) and pseudo-second-order (PSO) (Equation (7)) kinetic rate models were used to study the reaction kinetics for chromium (VI) adsorption by the three adsorbents $\left(\mathrm{AC}-\mathrm{Fe}_{3} \mathrm{O}_{4}, \mathrm{AC}-\mathrm{Fe}_{3} \mathrm{O}_{4}-\mathrm{SiO}_{2}\right.$, and $\left.\mathrm{AC}-\mathrm{Fe}_{3} \mathrm{O}_{4}-\mathrm{SiO}_{2}-\mathrm{PEI}\right)$. The Elovich model was also fitted to the kinetic data to confirm the chemisorption nature of the adsorption process expressed using Equation (8).

$$
\begin{gathered}
q_{t}=q_{e}\left[1-\exp \left(-k_{1} t\right)\right] \\
q_{t}=\frac{t k_{2} \cdot q_{e}^{2}}{\left(1+k_{2} t q_{e}\right)} \\
q_{t}=\frac{1}{\beta} \ln (1+\alpha \beta t)
\end{gathered}
$$

where $q_{t}(\mathrm{mg} / \mathrm{g})$ is the adsorption capacity of the adsorbent at time $t, k_{1}(1 / \mathrm{min})$ and $k_{2}(\mathrm{~g} / \mathrm{mg} / \mathrm{min})$ are the PFO and PSO rates constants, respectively. In Equation (8), $\beta$ $(\mathrm{mg} / \mathrm{g})$ denotes the desorption rate, $\alpha(\mathrm{mg} / \mathrm{g}$. $\mathrm{min})$ is the initial adsorption rate and $t$ is the time (min).

The data from fitting kinetics curves are referred to in Figure 10 and the numerical data is summarized in Table 3. The $\mathrm{R}^{2}$ and RSE were used to decide on which model was best fitted to the experimental data. The high $\mathrm{R}^{2}(0.949,0.948$, and 0.925$)$ and low RSE $(0.051$, 0.052 , and 0.075 ) values observed with the PSO model indicated its better fit compared to the PFO for $\mathrm{AC}-\mathrm{Fe}_{3} \mathrm{O}_{4}, \mathrm{AC}-\mathrm{Fe}_{3} \mathrm{O}_{4}-\mathrm{SiO}_{2}$, and $\mathrm{AC}-\mathrm{Fe}_{3} \mathrm{O}_{4}-\mathrm{SiO}_{2}-\mathrm{PEI}$, respectively. The Elovich error terms ( $\mathrm{R}^{2}$ and RSE) values were in agreement with the PSO data and suggested that chemisorption was the dominant mode of $\mathrm{Cr}(\mathrm{VI})$ removal. The high initial adsorption rates $(\alpha)$ show that the adsorption process was slow, probably due to the reaction being of chemical nature and poor porosity observed in Table 1. 

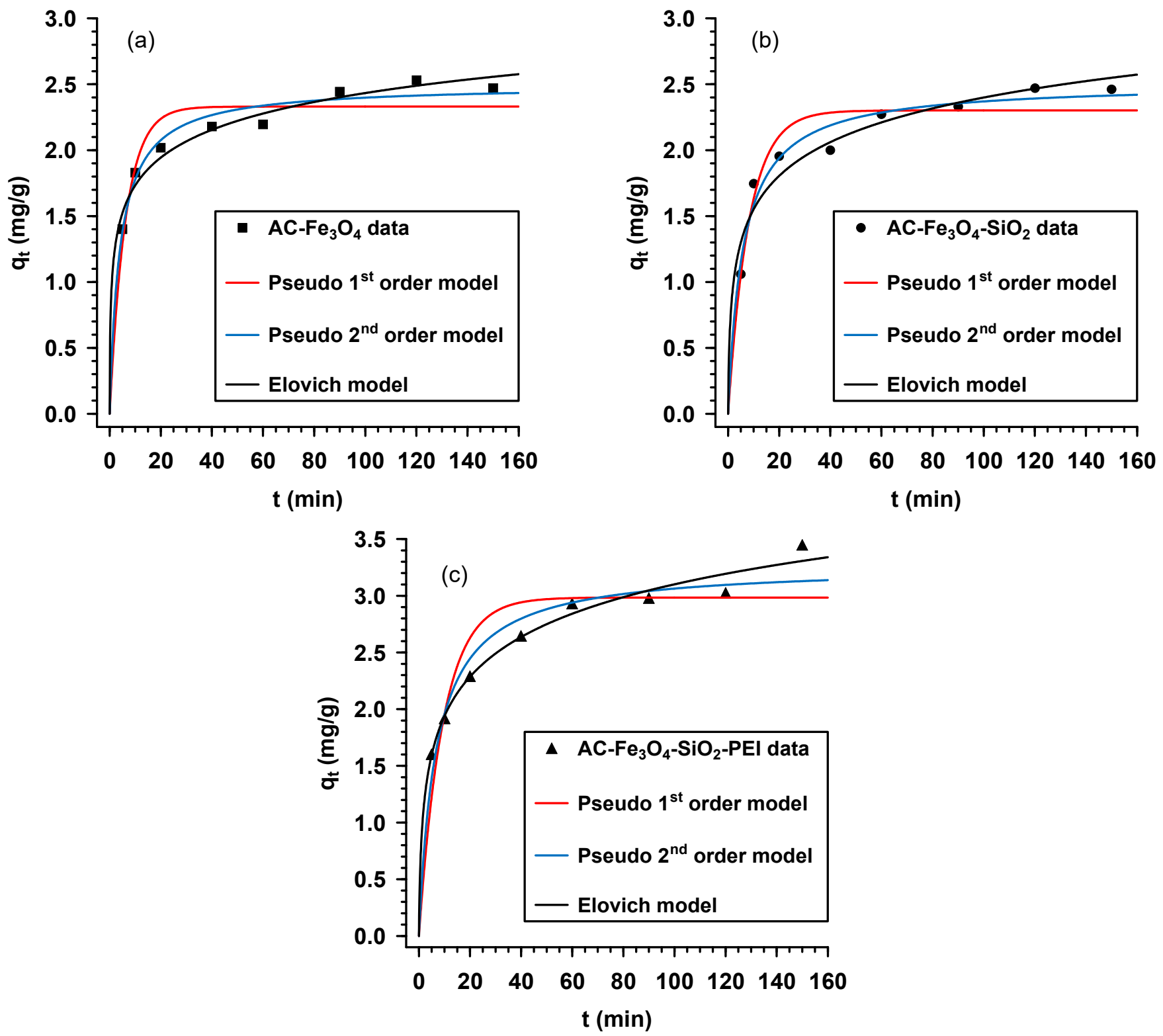

Figure 10. Kinetic modeling for the adsorption of $\mathrm{Cr}(\mathrm{VI})$ by $\mathrm{AC}-\mathrm{Fe}_{3} \mathrm{O}_{4}(\mathbf{a}), \mathrm{AC}-\mathrm{Fe}_{3} \mathrm{O}_{4}-\mathrm{SiO}_{2}(\mathbf{b})$, and $\mathrm{AC}-\mathrm{Fe} \mathrm{O}_{4}-\mathrm{SiO} \mathrm{O}_{2}-\mathrm{PEI}(\mathbf{c})$.

Table 3. Kinetics isotherm parameters of $\mathrm{AC}-\mathrm{Fe}_{3} \mathrm{O}_{4}, \mathrm{AC}-\mathrm{Fe}_{3} \mathrm{O}_{4}-\mathrm{SiO}_{2}$, and $\mathrm{AC}-\mathrm{Fe}_{3} \mathrm{O}_{4} \mathrm{SiO}_{2}$-PEI.

\begin{tabular}{|c|c|c|c|c|}
\hline Model & Parameters & $\mathrm{AC}-\mathrm{Fe}_{3} \mathrm{O}_{4}$ & $\mathrm{AC}-\mathrm{Fe}_{3} \mathrm{O}_{4}-\mathrm{SiO}_{2}$ & $\mathrm{AC}-\mathrm{Fe}_{3} \mathrm{O}_{4}-\mathrm{SiO}_{2}$-PEI \\
\hline \multirow{4}{*}{ Pseudo-first order } & $q_{t}(\mathrm{mg} / \mathrm{g})$ & 2.33 & 2.30 & 2.98 \\
\hline & $k_{1}(1 / \mathrm{min})$ & 0.16 & 0.12 & 0.11 \\
\hline & $\mathrm{R}^{2}$ & 0.829 & 0.889 & 0.794 \\
\hline & RSE & 0.171 & 0.111 & 0.206 \\
\hline \multirow{4}{*}{ Pseudo-second order } & $q_{t}(\mathrm{mg} / \mathrm{g})$ & 2.50 & 2.51 & 3.27 \\
\hline & $k_{2}((\mathrm{~g} /(\mathrm{mg} \min ))$ & 0.10 & 0.07 & 0.05 \\
\hline & $\mathrm{R}^{2}$ & 0.949 & 0.948 & 0.925 \\
\hline & RSE & 0.051 & 0.052 & 0.075 \\
\hline \multirow{4}{*}{ Elovich } & $\alpha(\mathrm{mg} /(\mathrm{g} \min ))$ & 8.98 & 2.41 & 2.25 \\
\hline & $\beta(\mathrm{mg} / \mathrm{g})$ & 3.28 & 2.70 & 1.96 \\
\hline & $\mathrm{R}^{2}$ & 0.953 & 0.914 & 0.978 \\
\hline & RSE & 0.047 & 0.086 & 0.022 \\
\hline
\end{tabular}




\subsection{Performance Comparison}

The $\mathrm{Cr}(\mathrm{VI})$ adsorption capacities of $\mathrm{AC}-\mathrm{Fe}_{3} \mathrm{O}_{4}, \mathrm{AC}-\mathrm{Fe}_{3} \mathrm{O}_{4}-\mathrm{SiO}_{2}, \mathrm{AC}-\mathrm{Fe}_{3} \mathrm{O}_{4}-\mathrm{SiO}_{2}$-PEI were compared to similar materials found in the literature (Table 4). The adsorbents were compared based on initial solution $\mathrm{pH}$, initial $\mathrm{Cr}(\mathrm{VI})$ concentration, and Langmuir adsorption capacity $q_{m L}$. Table 4 reveals that the adsorbents worked better at acidic conditions for the uptake of $\mathrm{Cr}(\mathrm{VI})$ from an aqueous solution. Numerous studies in the literature have reported the existence of electrostatic attraction forces between anionic $\mathrm{Cr}(\mathrm{VI})$ and positively charged adsorbent surface groups as the mode of the removal $[33,46,47]$. The initial concentration of $\mathrm{Cr}(\mathrm{VI}), \mathrm{C}_{0}$, being studied varies as depicted in Table 3 , depending on the type of water targeted for the clean-up. Those targeting wastewater normally use a high $C_{o}$ concentration of $\mathrm{Cr}(\mathrm{VI})$, while those aiming for analysis of drinking water use low concentration. The selected iron oxide functionalized materials presented in Table 4 also reveal that producing these types of materials that possess high adsorption capacity values presents a challenge [48]. Based on this observation, it can be concluded that the materials produced in this study performed fairly well in comparison to the literature. Hence, the current material extends the research on the type of adsorbents that can be evaluated for $\mathrm{Cr}(\mathrm{VI})$ adsorption. It has been reported that despite the high content of amino groups on PEI, high loading of PEI may lead to reduced surface areas, which may lead to lower adsorption capacities [28]. Lower adsorption capacities were observed with PEI-loaded adsorbents as compared to magnetite-loaded AC due to reduced surface areas.

Table 4. Comparison of adsorption capacities of $\mathrm{Cr}(\mathrm{VI})$ by different adsorbents as to $\mathrm{AC}-\mathrm{Fe}_{3} \mathrm{O}_{4}$, $\mathrm{AC}-\mathrm{Fe}_{3} \mathrm{O}_{4} \mathrm{SiO}_{2}$ and $\mathrm{AC}-\mathrm{Fe}_{3} \mathrm{O}_{4}-\mathrm{SiO}_{2}$-PEI.

\begin{tabular}{|c|c|c|c|c|}
\hline Adsorbent & $\mathrm{pH}$ & $C_{o}(\mathrm{mg} / \mathrm{L})$ & $q_{m L}(\mathrm{mg} / \mathrm{g})$ & Reference \\
\hline Magnetic biochar & 3 & 100 & 8.35 & [35] \\
\hline MBC/PPy & 3 & 10 & 19.23 & [49] \\
\hline Magnetic biochar (MMABC) & 3 & 10 & 25.27 & {$[50]$} \\
\hline $\mathrm{Fe}_{3} \mathrm{O}_{4}$-PEI800-MNT & $1-9$ & $10-25$ & 8.77 & [51] \\
\hline $\mathrm{Fe}_{3} \mathrm{O}_{4}$-PEI25000-MNT & $1-9$ & $10-25$ & 7.69 & {$[51]$} \\
\hline $\mathrm{AC}-\mathrm{Fe}_{3} \mathrm{O}_{4}$ & 3 & 5 & 5.43 & This study \\
\hline $\mathrm{AC}-\mathrm{Fe}_{3} \mathrm{O}_{4}-\mathrm{SiO}_{2}$ & 1 & 5 & 4.67 & This study \\
\hline $\mathrm{AC}-\mathrm{Fe}_{3} \mathrm{O}_{4}-\mathrm{SiO}_{2}$-PEI & 1 & 5 & 8.00 & This study \\
\hline
\end{tabular}

\subsection{Thermodynamic Studies}

The thermodynamic studies for the adsorption of $\mathrm{Cr}(\mathrm{VI})$ by $\mathrm{AC}-\mathrm{Fe}_{3} \mathrm{O}_{4}, \mathrm{AC}^{-} \mathrm{Fe}_{3} \mathrm{O}_{4}$ $\mathrm{SiO}_{2}$, and $\mathrm{AC}-\mathrm{Fe}_{3} \mathrm{O}_{4}-\mathrm{SiO}_{2}-\mathrm{PEI}$ adsorbents were evaluated at different temperatures $(25,35$, and $45^{\circ} \mathrm{C}$ ) to predict the adsorption nature and spontaneity of the process. Parameters such as the entropy change $\left(\Delta S^{o}, \mathrm{~J} /(\mathrm{mol} \mathrm{K})\right)$, enthalpy change $\left(\Delta H^{\circ}, \mathrm{J} / \mathrm{mol}\right)$, and Gibb's free energy $\left(\Delta G^{o}, \mathrm{~J} / \mathrm{mol}\right)$ were calculated by relating Gibb's free energy to the equilibrium constant Kc using Equations (9)-(12).

$$
\begin{gathered}
\Delta G^{o}=\Delta H^{o}-T \Delta S^{o} \\
\Delta G^{o}=-R T \ln K_{c}^{o} \\
K_{c}^{o}=\frac{M w_{(H C r O 4-)} \cdot 1000 \cdot b \cdot\left[\mathrm{HCrO}_{4}^{-}\right]^{\mathrm{o}}}{\gamma} \\
\ln \left(\frac{M w_{(H C r O 4-)} \cdot 1000 \cdot b \cdot\left[\mathrm{HCrO}_{4}^{-}\right]^{o}}{\gamma}\right)=\frac{\Delta S^{o}}{R}-\frac{\Delta H^{o}}{R T}
\end{gathered}
$$

where $\Delta G^{\circ}$ is Gibb's free energy $(\mathrm{J} / \mathrm{mol}), R$ is the universal gas constant $(8.3144 \mathrm{~J} / \mathrm{mol} \mathrm{K})$, $K_{c}^{o}$ is the dimensionless equilibrium constant, $\mathrm{Mw} w_{(\mathrm{HCrO}-)}$ is the molecular weight of model pollutant $\mathrm{HCrO}_{4}{ }^{-}, \gamma$ is the coefficient of activity (dimensionless) [52], $b$ is the Langmuir 
isotherm constant $(\mathrm{L} / \mathrm{mg}),\left[\mathrm{HCrO}_{4}{ }^{-}\right]^{\circ}$ is the standard concentration of the adsorbate $(1 \mathrm{~mol} / \mathrm{L})$ and $T$ is the temperature $(\mathrm{K})$.

The $\Delta G^{o}, \Delta H^{o}$ and $\Delta S^{o}$ results are stipulated in Table 5. The $\Delta G^{o}$ values were found to be negative for $\mathrm{AC}-\mathrm{Fe}_{3} \mathrm{O}_{4}, \mathrm{AC}-\mathrm{Fe}_{3} \mathrm{O}_{4}-\mathrm{SiO}_{2}$ and $\mathrm{AC}-\mathrm{Fe}_{3} \mathrm{O}_{4}-\mathrm{SiO} \mathrm{O}_{2}$ - $\mathrm{PEI}$ at all temperatures investigated $(298,308$, and $318 \mathrm{~K})$. The values of $\Delta G^{o}$ ranged between -17 and $-36 \mathrm{~kJ} / \mathrm{mol}$, indicating a spontaneous adsorption process. The positive $\Delta H^{o}$ values $(871.45 \mathrm{~kJ} / \mathrm{mol}$ for $\mathrm{AC}-\mathrm{Fe}_{3} \mathrm{O}_{4}-\mathrm{SiO}_{2}-\mathrm{PEI}$ ) indicated that the $\mathrm{Cr}(\mathrm{VI})$ adsorption process was endothermic and fell outside the $2-30 \mathrm{~kJ} / \mathrm{mol}$ range which is characteristic of chemisorption [49]. In addition, the positive $\Delta H^{o}$ values are associated with the proven endothermic reaction of $\mathrm{Cr}(\mathrm{VI})$ to $\mathrm{Cr}(\mathrm{III})$ reduction [33,53]. The adsorption of $\mathrm{Cr}(\mathrm{VI})$ by $\mathrm{AC}-\mathrm{Fe}_{3} \mathrm{O}_{4}-\mathrm{SiO}_{2}$ and $\mathrm{AC}-\mathrm{Fe}_{3} \mathrm{O}_{4}-\mathrm{SiO}_{2}-\mathrm{PEI}$ was regarded as highly randomized, as the $\Delta S^{0}$ values were above zero [54]. The adsorption of $\mathrm{Cr}(\mathrm{VI})$ using $\mathrm{AC}-\mathrm{Fe}_{3} \mathrm{O}_{4}-\mathrm{SiO}_{2}$ and $\mathrm{AC}-\mathrm{Fe}_{3} \mathrm{O}_{4}-\mathrm{SiO}_{2}-\mathrm{PEI}$ adsorbents was dominated by entropy change as opposed to enthalpy change due to $\left|T \Delta S^{\circ}\right|>\left|\Delta H^{\circ}\right|$ [55].

Table 5. Thermodynamics parameters of $\mathrm{AC}-\mathrm{Fe}_{3} \mathrm{O}_{4}, \mathrm{AC}-\mathrm{Fe}_{3} \mathrm{O}_{4}-\mathrm{SiO}_{2}$, and $\mathrm{AC}-\mathrm{Fe}_{3} \mathrm{O}_{4}-\mathrm{SiO}_{2}-\mathrm{PEI}$ at different temperatures.

\begin{tabular}{|c|c|c|c|c|c|c|c|}
\hline Adsorbent & $T(\mathrm{~K})$ & $b(\mathrm{~L} / \mathrm{mg})$ & $\ln \left(K_{c}^{0}\right)$ & $\Delta G^{o}(\mathrm{~kJ} / \mathrm{mol})$ & $\left|T \Delta S^{\circ}\right|(\mathrm{kJ} / \mathrm{mol})$ & $\Delta H^{o}(\mathrm{~kJ} / \mathrm{mol})$ & $\Delta S^{o}(\mathrm{~J} /(\mathrm{mol} \mathrm{K}))$ \\
\hline \multirow{3}{*}{$\mathrm{AC}-\mathrm{Fe}_{3} \mathrm{O}_{4}$} & 298 & 20.85 & 14.71 & -25.43 & 160.03 & 133.45 & 537.00 \\
\hline & 308 & 5.51 & 13.38 & -34.25 & 165.40 & & \\
\hline & 318 & 7.07 & 13.68 & -36.17 & 170.77 & & \\
\hline \multirow{3}{*}{$\mathrm{AC}-\mathrm{Fe}_{3} \mathrm{O}_{4}-\mathrm{SiO}_{2}$} & 298 & 5.44 & 13.36 & -23.11 & 160.62 & 136.09 & 539.00 \\
\hline & 308 & 3.10 & 12.80 & -32.78 & 166.01 & & \\
\hline & 318 & 3.16 & 12.82 & -33.89 & 171.40 & & \\
\hline \multirow[t]{3}{*}{$\mathrm{AC}-\mathrm{Fe}_{3} \mathrm{O}_{4}-\mathrm{SiO}_{2}$-PEI } & 298 & 0.15 & 9.77 & -16.90 & 881.63 & 871.45 & 2958.50 \\
\hline & 308 & 0.25 & 10.28 & -26.33 & 911.22 & & \\
\hline & 318 & 0.80 & 28.77 & -76.07 & 940.80 & & \\
\hline
\end{tabular}

\section{Conclusions}

Amino functionalized activated carbon silica composites were prepared and explored as adsorbents for the removal of $\mathrm{Cr}(\mathrm{VI})$ from aqueous solutions. The FTIR analysis showed the presence of asymmetric and symmetric peaks of $\mathrm{Fe}-\mathrm{O}, \mathrm{Si}-\mathrm{O}-\mathrm{Si}$, and $\mathrm{Si}-\mathrm{OH}$ bonds at 533,791 , and $1054 \mathrm{~cm}^{-1}$ alluding to the successful incorporation of $\mathrm{Fe}_{3} \mathrm{O}_{4}$ and $\mathrm{SiO}_{2}$ on the surface of the AC. The EDS data further confirmed the presence of $\mathrm{Fe}, \mathrm{Si}, \mathrm{O}$, and C atoms in proportional amounts on the adsorbents. Small deposits representing $\mathrm{Fe}_{3} \mathrm{O}_{4}$ precipitates were observed in the large pores of $\mathrm{AC}-\mathrm{Fe}_{3} \mathrm{O}_{4} \mathrm{SEM}$ images. The BET surface area of $\mathrm{AC}-\mathrm{Fe}_{3} \mathrm{O}_{4}$ decreased from 387 to $0.15 \mathrm{~m}^{2} / \mathrm{g}$ following the attachment of $\mathrm{SiO}_{2}$ and PEI to the biobased carbon. Attachment of $\mathrm{SiO}_{2}$ on $\mathrm{AC}-\mathrm{Fe}_{3} \mathrm{O}_{4}$ resulted in increased $\% \mathrm{C}$ and $\% \mathrm{H}$ correlating to the inclusion of $\mathrm{CH}_{3}-\mathrm{CH}_{2}$ chains of TEOS. The isoelectric points of $\mathrm{AC}-\mathrm{Fe}_{3} \mathrm{O}_{4}, \mathrm{AC}-\mathrm{Fe}_{3} \mathrm{O}_{4}-\mathrm{SiO}_{2}$, and $\mathrm{AC}-\mathrm{Fe}_{3} \mathrm{O}_{4}-\mathrm{SiO}_{2}-\mathrm{PEI}$ were at $\mathrm{pH} 4.95,3.53$, and 11.69, respectively. The high positivity in isoelectric charge predicts increased electrostatic interaction between the positively charged adsorbent and negatively charged $\mathrm{Cr}(\mathrm{VI})$ ions. The batch adsorption experiments displayed optimum conditions of $\mathrm{pH} 3$ and 1, initial concentration $5 \mathrm{mg} / \mathrm{L}, 0.15 \mathrm{~g}$ adsorbent mass, $120 \mathrm{~min}$ contact time, and $45^{\circ} \mathrm{C}$ temperature. The experimental data were best fitted to Langmuir adsorption isotherm for all three prepared adsorbents, predicting that the adsorption process occurred over a homogenous, mono-layered coverage. The kinetics data were best fitted to the pseudo-second-order rate model. According to the thermodynamics parameters, the adsorption of $\mathrm{Cr}(\mathrm{VI})$ by the composites was spontaneous and endothermic. The high enthalpy change energy suggested chemical transformation of adsorbed $\mathrm{Cr}(\mathrm{VI})$ into $\mathrm{Cr}$ (III), thus overruling the physisorption as the dominant mechanism but chemisorption. Additionally, the poor porosity of the main sorbent favored the chemisorption uptake of $\mathrm{Cr}(\mathrm{VI})$. In comparison to similar adsorbents, the $\mathrm{AC}-\mathrm{Fe}_{3} \mathrm{O}_{4}, \mathrm{AC}-\mathrm{Fe}_{3} \mathrm{O}_{4}-\mathrm{SiO}_{2}$, and $\mathrm{AC}-\mathrm{Fe}_{3} \mathrm{O}_{4}-\mathrm{SiO}_{2}-\mathrm{PEI}$ showed promising adsorption capacities and can be used as adsorbents for the removal of $\mathrm{Cr}(\mathrm{VI})$ from dilute aqueous solutions but adsorbents need improvement or testing using other pollutants like organic dyes. 
Author Contributions: M.C.Q.: Investigation, Methodology, Data curation, Writing-Original draft preparation. P.N.N.: Supervision, Conceptualization, Methodology, Resources, Reviewing and Editing. V.E.P.: Conceptualization, Methodology, Software, Supervision, Funding acquisition, Reviewing and Editing. All authors have read and agreed to the published version of the manuscript.

Funding: The authors thank the financial support from the South African National Research Foundation (Grant numbers: TTK13061018779 and TTK16051164648).

Institutional Review Board Statement: Not applicable.

Informed Consent Statement: Not applicable.

Data Availability Statement: The data presented in this study are available on request from the corresponding author.

Acknowledgments: We thank Malvin Moyo for the technical support.

Conflicts of Interest: The authors declare no conflict of interest.

\section{References}

1. Heiderscheidt, E.; Postila, H.; Leiviskä, T. Removal of metals from wastewaters by mineral and biomass-based sorbents applied in continuous-flow continuous stirred tank reactors followed by sedimentation. Sci. Total Environ. 2020, 700, 135079. [CrossRef]

2. White, P.J.; Brown, P.H. Plant nutrition for sustainable development and global health. Ann. Bot. 2010, 105, 1073-1080. [CrossRef] [PubMed]

3. Bartlett, R.J. Chromium cycling in soils and water: Links, gaps, and methods. Environ. Health Perspect. 1991, 92, 17-24. [CrossRef] [PubMed]

4. Kumar, A.; Joseph, S.; Tsechansky, L.; Schreiter, I.J.; Schüth, C.; Taherysoosavi, S.; Mitchell, D.R.G.; Graber, E.R. Mechanistic evaluation of biochar potential for plant growth promotion and alleviation of chromium-induced phytotoxicity in Ficus elastica. Chemosphere 2020, 243, 125332. [CrossRef] [PubMed]

5. Pap, S.; Bezanovic, V.; Radonic, J.; Babic, A.; Saric, S.; Adamovic, D.; Turk Sekulic, M. Synthesis of highly-efficient functionalized biochars from fruit industry waste biomass for the removal of chromium and lead. J. Mol. Liq. 2018, 268, 315-325. [CrossRef]

6. Qiu, B.; Wang, Y.; Sun, D.; Wang, Q.; Zhang, X.; Weeks, B.L.; O'Connor, R.; Huang, X.; Wei, S.; Guo, Z. Cr(vi) removal by magnetic carbon nanocomposites derived from cellulose at different carbonization temperatures. J. Mater. Chem. A 2015, 3, 9817-9825. [CrossRef]

7. Rai, M.K.; Shahi, G.; Meena, V.; Meena, R.; Chakraborty, S.; Singh, R.S.; Rai, B.N. Removal of hexavalent chromium Cr (VI) using activated carbon prepared from mango kernel activated with $\mathrm{H}_{3} \mathrm{PO}_{4}$. Resour. Technol. 2016, 2, S63-S70. [CrossRef]

8. Corazza, M.Z.; Somera, B.F.; Segatelli, M.G.; Tarley, C.R.T. Grafting 3-mercaptopropyl trimethoxysilane on multi-walled carbon nanotubes surface for improving on-line cadmium(II) preconcentration from water samples. J. Hazard. Mater. 2012, 243, 326-333. [CrossRef]

9. Kononova, O.N.; Bryuzgina, G.L.; Apchitaeva, O.V.; Kononov, Y.S. Ion exchange recovery of chromium (VI) and manganese (II) from aqueous solutions. Arab. J. Chem. 2019, 12, 2713-2720. [CrossRef]

10. Mnif, A.; Bejaoui, I.; Mouelhi, M.; Hamrouni, B. Hexavalent Chromium Removal from Model Water and Car Shock Absorber Factory Effluent by Nanofiltration and Reverse Osmosis Membrane. Int. J. Anal. Chem. 2017, 2017, 7415708. [CrossRef]

11. Rol, F.; Belgacem, M.N.; Gandini, A.; Bras, J. Recent advances in surface-modified cellulose nanofibrils. Prog. Polym. Sci. 2019, 88, 241-264. [CrossRef]

12. Stylianou, S.; Simeonidis, K.; Mitrakas, M.; Zouboulis, A.; Ernst, M.; Katsoyiannis, I.A. Reductive precipitation and removal of $\mathrm{Cr}(\mathrm{VI})$ from groundwaters by pipe flocculation-microfiltration. Environ. Sci. Pollut. Res. 2018, 25, 12256-12262. [CrossRef] [PubMed]

13. He, R.; Yuan, X.; Huang, Z.; Wang, H.; Jiang, L.; Huang, J.; Tan, M.; Li, H. Activated biochar with iron-loading and its application in removing Cr (VI) from aqueous solution. Colloids Surfaces A Physicochem. Eng. Asp. 2019, 579, 123642. [CrossRef]

14. Miao, M.S.; Wang, Y.N.; Kong, Q.; Shu, L. Adsorption kinetics and optimum conditions for Cr(VI) removal by activated carbon prepared from luffa sponge. Desalin. Water Treat. 2016, 57, 7763-7772. [CrossRef]

15. Gottipati, R.; Mishra, S. Preparation of microporous activated carbon from Aegle Marmelos fruit shell and its application in removal of chromium(VI) from aqueous phase. J. Ind. Eng. Chem. 2016, 36, 355-363. [CrossRef]

16. Cai, W.; Li, Z.; Wei, J.; Liu, Y. Synthesis of peanut shell based magnetic activated carbon with excellent adsorption performance towards electroplating wastewater. Chem. Eng. Res. Des. 2018, 140, 23-32. [CrossRef]

17. Hlungwane, L.; Viljoen, E.L.; Pakade, V.E. Macadamia nutshells-derived activated carbon and attapulgite clay combination for synergistic removal of $\mathrm{Cr}(\mathrm{VI})$ and $\mathrm{Cr}(\mathrm{III})$. Adsorpt. Sci. Technol. 2018, 36, 713-731. [CrossRef]

18. Zeng, Q.; Huang, Y.; Huang, L.; Hu, L.; Xiong, D.; Zhong, H. Efficient removal of hexavalent chromium in a wide $\mathrm{pH}$ range by composite of $\mathrm{SiO}_{2}$ supported nano ferrous oxalate. Chem. Eng. J. 2020, 383, 123209. [CrossRef] 
19. Zeng, Q.; Huang, Y.; Wang, H.; Huang, L.; Hu, L.; Zhong, H. A novel composite of almandine supported humboldtine nanospheres, in situ synthesized from natural almandine, possesses high removal efficiency of $\mathrm{Cr}$ (VI) over a wide $\mathrm{pH}$ range. J. Hazard. Mater. 2020, 383, 121199. [CrossRef]

20. Ta, T.K.H.; Trinh, M.T.; Long, N.V.; Nguyen, T.T.M.; Nguyen, T.L.T.; Thuoc, T.L.; Phan, B.T.; Mott, D.; Maenosono, S.; Tran-Van, H.; et al. Synthesis and surface functionalization of $\mathrm{Fe}_{3} \mathrm{O}_{4}-\mathrm{SiO}_{2}$ core-shell nanoparticles with 3-glycidoxypropyltrimeth oxysilane and 1,1'-carbonyldiimidazole for bio-applications. Colloids Surfaces A Physicochem. Eng. Asp. 2016, 504, $376-383$. [CrossRef]

21. Shi, S.; Yang, J.; Liang, S.; Li, M.; Gan, Q.; Xiao, K.; Hu, J. Enhanced Cr(VI) removal from acidic solutions using biochar modified by $\mathrm{Fe}_{3} \mathrm{O}_{4} @ \mathrm{SiO}_{2}-\mathrm{NH}_{2}$ particles. Sci. Total Environ. 2018, 628-629, 499-508. [CrossRef]

22. Jiang, Y.; Liu, Z.; Zeng, G.; Liu, Y.; Shao, B.; Li, Z.; Liu, Y.; Zhang, W.; He, Q. Polyaniline-based adsorbents for removal of hexavalent chromium from aqueous solution: A mini review. Environ. Sci. Pollut. Res. 2018, 25, 6158-6174. [CrossRef]

23. Zeng, Q.; Hu, Y.; Yang, Y.; Hu, L.; Zhong, H.; He, Z. Cell envelop is the key site for Cr (VI) reduction by Oceanobacillus oncorhynchi W4, a newly isolated Cr (VI) reducing bacterium. J. Hazard. Mater. 2019, 368, 149-155. [CrossRef] [PubMed]

24. Mo, Y.; Wang, S.; Vincent, T.; Desbrieres, J.; Faur, C.; Guibal, E. New highly-percolating alginate-PEI membranes for efficient recovery of chromium from aqueous solutions. Carbohydr. Polym. 2019, 225, 115177. [CrossRef]

25. Zhang, S.; Wang, Z.; Chen, H.; Kai, C.; Jiang, M.; Wang, Q.; Zhou, Z. Polyethylenimine functionalized Fe 3 O 4 /steam-exploded rice straw composite as an efficient adsorbent for Cr(VI) removal. Appl. Surf. Sci. 2018, 440, 1277-1285. [CrossRef]

26. Moyo, M.; Modise, S.J.; Pakade, V.E. Palladium nanoparticles dispersed on functionalized macadamia nutshell biomass for formic acid-mediated removal of chromium(VI) from aqueous solution. Sci. Total Environ. 2020, 743, 140614. [CrossRef]

27. Tangtubtim, S.; Saikrasun, S. Adsorption behavior of polyethyleneimine-carbamate linked pineapple leaf fiber for $\mathrm{Cr}(\mathrm{VI})$ removal. Appl. Surf. Sci. 2019, 467-468, 596-607. [CrossRef]

28. Geng, J.; Yin, Y.; Liang, Q.; Zhu, Z.; Luo, H. Polyethyleneimine cross-linked graphene oxide for removing hazardous hexavalent chromium: Adsorption performance and mechanism. Chem. Eng. J. 2019, 361, 1497-1510. [CrossRef]

29. Liu, Y.; Hu, J.; Li, Y.; Wei, H.P.; Li, X.S.; Zhang, X.H.; Chen, S.M.; Chen, X.Q. Synthesis of polyethyleneimine capped carbon dots for preconcentration and slurry sampling analysis of trace chromium in environmental water samples. Talanta 2015, 134, 16-23. [CrossRef] [PubMed]

30. Fatehi, M.H.; Shayegan, J.; Zabihi, M.; Goodarznia, I. Functionalized magnetic nanoparticles supported on activated carbon for adsorption of $\mathrm{Pb}(\mathrm{II})$ and $\mathrm{Cr}(\mathrm{VI})$ ions from saline solutions. J. Environ. Chem. Eng. 2017, 5, 1754-1762. [CrossRef]

31. Al-Ghouti, M.A.; Da'ana, D.A. Guidelines for the use and interpretation of adsorption isotherm models: A review. J. Hazard. Mater. 2020, 393, 122383. [CrossRef] [PubMed]

32. Lee, M.Y.; Lee, J.H.; Chung, J.W.; Kwak, S.Y. Hydrophilic and positively charged polyethylenimine-functionalized mesoporous magnetic clusters for highly efficient removal of $\mathrm{Pb}(\mathrm{II})$ and $\mathrm{Cr}(\mathrm{VI})$ from wastewater. J. Environ. Manag. 2018, 206, 740-748. [CrossRef]

33. Liang, X.; Fan, X.; Li, R.; Li, S.; Shen, S.; Hu, D. Efficient removal of Cr(VI) from water by quaternized chitin/branched polyethylenimine biosorbent with hierarchical pore structure. Bioresour. Technol. 2018, 250, 178-184. [CrossRef]

34. Yin, C.Y.; Aroua, M.K.; Daud, W.M.A.W. Impregnation of palm shell activated carbon with polyethyleneimine and its effects on Cd2+ adsorption. Colloids Surfaces A Physicochem. Eng. Asp. 2007, 307, 128-136. [CrossRef]

35. Zhong, D.; Zhang, Y.; Wang, L.; Chen, J.; Jiang, Y.; Tsang, D.C.W.; Zhao, Z.; Ren, S.; Liu, Z.; Crittenden, J.C. Mechanistic insights

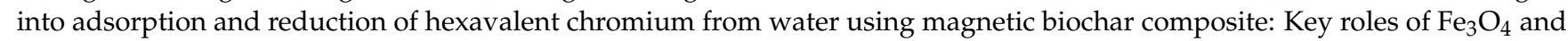
persistent free radicals. Environ. Pollut. 2018, 243, 1302-1309. [CrossRef]

36. Lesaoana, M.; Mlaba, R.P.V.; Mtunzi, F.M.; Klink, M.J.; Edijike, P.; Pakade, V.E. Influence of inorganic acid modification on Cr(VI) adsorption performance and the physicochemical properties of activated carbon. S. Afr. J. Chem. Eng. 2019, 28. [CrossRef]

37. Li, B.; Zhang, L.; Yin, W.; Lv, S.; Li, P.; Zheng, X.; Wu, J. Effective immobilization of hexavalent chromium from drinking water by nano-FeOOH coating activated carbon: Adsorption and reduction. J. Environ. Manag. 2021, 277, 111386. [CrossRef]

38. Zhang, T.; Yue, X.; Zhang, K.; Li, J.; Zhu, C.; Zhang, L.; Chen, W. Selective adsorption of $\mathrm{CuSO}_{4}$ from mixed sulfate solutions by $\mathrm{Cu}(\mathrm{II})$ ion-imprinted polymers containing salicylaldoximes, ammonium cations, and tertiary amino groups. Mater. Des. 2016, 107, 372-377. [CrossRef]

39. Chen, Q.; Zhu, R.; Zhu, Y.; Liu, J.; Zhu, L.; Ma, L.; Chen, M. Adsorption of polyhydroxy fullerene on polyethylenimine-modified montmorillonite. Appl. Clay Sci. 2016, 132-133, 412-418. [CrossRef]

40. Nchoe, O.B.; Ntuli, T.D.; Klink, M.J.; Mtunzi, F.M.; Pakade, V.E. A comparative study of acid, base and Fenton-like reagent treated biomass for $\mathrm{Cr}(\mathrm{VI})$ sequestration from aqueous solutions. Water Environ. Res. 2020, 93, 370-383. [CrossRef]

41. Yan, Y.; An, Q.; Xiao, Z.; Zheng, W.; Zhai, S. Flexible core-shell/bead-like alginate@PEI with exceptional adsorption capacity, recycling performance toward batch and column sorption of $\mathrm{Cr}(\mathrm{VI})$. Chem. Eng. J. 2017, 313, 475-486. [CrossRef]

42. Zhao, D.; Gao, X.; Wu, C.; Xie, R.; Feng, S.; Chen, C. Facile preparation of amino functionalized graphene oxide decorated with $\mathrm{Fe}_{3} \mathrm{O}_{4}$ nanoparticles for the adsorption of Cr(VI). Appl. Surf. Sci. 2016, 384, 1-9. [CrossRef]

43. Chen, Y.; Wang, B.; Xin, J.; Sun, P.; Wu, D. Adsorption behavior and mechanism of Cr(VI) by modified biochar derived from Enteromorpha prolifera. Ecotoxicol. Environ. Saf. 2018, 164, 440-447. [CrossRef] 
44. Chang, J.; Wang, H.; Zhang, J.; Xue, Q.; Chen, H. New insight into adsorption and reduction of hexavalent chromium by magnetite: Multi-step reaction mechanism and kinetic model developing. Colloids Surfaces A Physicochem. Eng. Asp. 2021, 611, 125784. [CrossRef]

45. Nkutha, C.S.; Diagboya, P.N.; Mtunzi, F.M.; Dikio, E.D. Application of eco-friendly multifunctional porous graphene oxide for adsorptive sequestration of chromium in aqueous solution. Water Environ. Res. 2020, 92, 1070-1079. [CrossRef]

46. Pakade, V.E.; Maremeni, L.C.; Ntuli, T.D.; Tavengwa, N.T. Application of quaternized activated carbon derived from macadamia nutshells for the removal of hexavalent chromium from aqueous solutions. S. Afr. J. Chem. 2016, 69, 180-188. [CrossRef]

47. Niazi, L.; Lashanizadegan, A.; Sharififard, H. Chestnut oak shells activated carbon: Preparation, characterization and application for Cr (VI) removal from dilute aqueous solutions. J. Clean. Prod. 2018, 185, 554-561. [CrossRef]

48. Qhubu, M.C.; Mgidlana, L.G.; Madikizela, L.M.; Pakade, V.E. Preparation, characterization and application of activated clay biochar composite for removal of $\mathrm{Cr}(\mathrm{VI})$ in water: Isotherms, kinetics and thermodynamics. Mater. Chem. Phys. 2021, 260, 124165. [CrossRef]

49. Yang, Y.; Chen, N.; Feng, C.; Li, M.; Gao, Y. Chromium removal using a magnetic corncob biochar/polypyrrole composite by adsorption combined with reduction: Reaction pathway and contribution degree. Colloids Surfaces A Physicochem. Eng. Asp. 2018, 556, 201-209. [CrossRef]

50. Zhang, X.; Lv, L.; Qin, Y.; Xu, M.; Jia, X.; Chen, Z. Removal of aqueous Cr(VI) by a magnetic biochar derived from Melia azedarach wood. Bioresour. Technol. 2018, 256,1-10. [CrossRef]

51. Larraza, I.; López-Gónzalez, M.; Corrales, T.; Marcelo, G. Hybrid materials: Magnetite-Polyethylenimine-Montmorillonite, as magnetic adsorbents for $\mathrm{Cr}(\mathrm{VI})$ water treatment. J. Colloid Interface Sci. 2012, 385, 24-33. [CrossRef] [PubMed]

52. Lima, E.C.; Hosseini-Bandegharaei, A.; Moreno-Piraján, J.C.; Anastopoulos, I. A critical review of the estimation of the thermodynamic parameters on adsorption equilibria. Wrong use of equilibrium constant in the Van't Hoof equation for calculation of thermodynamic parameters of adsorption. J. Mol. Liq. 2019, 273, 425-434. [CrossRef]

53. Zhang, Y.; Xu, M.; Li, H.; Ge, H.; Bian, Z. The enhanced photoreduction of $\mathrm{Cr}(\mathrm{VI})$ to $\mathrm{Cr}(\mathrm{III})$ using carbon dots coupled TiO 2 mesocrystals. Appl. Catal. B Environ. 2018, 226, 213-219. [CrossRef]

54. Tran, H.N.; You, S.J.; Chao, H.P. Thermodynamic parameters of cadmium adsorption onto orange peel calculated from various methods: A comparison study. J. Environ. Chem. Eng. 2016, 4, 2671-2682. [CrossRef]

55. Hokkanen, S.; Bhatnagar, A.; Repo, E.; Lou, S.; Sillanpää, M. Calcium hydroxyapatite microfibrillated cellulose composite as a potential adsorbent for the removal of $\mathrm{Cr}(\mathrm{VI})$ from aqueous solution. Chem. Eng. J. 2016, 283, 445-452. [CrossRef] 